Article

\title{
Relationship between the Pore Structure of Mesoporous Silica Supports and the Activity of Nickel Nanocatalysts in the $\mathrm{CO}_{2}$ Reforming of Methane
}

\author{
Mohamad Hassan Amin (D) \\ School of Science, RMIT University, 3001 Melbourne, Australia; mohamadhassan.amin@rmit.edu.au or \\ doctoramin@gmail.com
}

Received: 9 December 2019; Accepted: 30 December 2019; Published: 1 January 2020

\begin{abstract}
The question remains over the role of the pore structure of the support material on the catalytic behaviour of $\mathrm{Ni}$ catalysts during the $\mathrm{CO}_{2} /$ dry reforming of methane (DRM). For this reason, a series of mesoporous materials with different pore structures, namely MCM-41, KIT-6, tri-modal porous silica (TMS), SBA-15 and mesostructured cellular foams (MCFs) were synthesised via hydrothermal synthesis methods and further impregnated with $15 \mathrm{wt} . \% \mathrm{NiO}(11.8 \mathrm{wt}$ \% $\mathrm{Ni})$. It was observed that synthesised TMS is a promising catalyst support for DRM as Ni/TMS gave the highest activity and stability among these materials as well as the Ni catalysts supported on classic ordered mesoporous silicates support reported in the literature at the relatively low temperature $\left(700^{\circ} \mathrm{C}\right)$. On the other hand, Ni supported on CMC-41 exhibited the lowest activity among them. To understand the reason for this difference, the physicochemical properties of these materials were characterised in detail. The results show that the thickness of the silica wall and the pore size of the support material play a critical role in the catalytic activity of $\mathrm{Ni}$ catalysts in the $\mathrm{CO}_{2}$ reforming of methane.
\end{abstract}

Keywords: MCM-41; SBA-15; KIT-6; tri-modal porous silica; mesostructured cellular foams

\section{Introduction}

The discovery of Mobil Crystalline Materials, such as MCM-41 in 1992 by Mobil Oil Corporation scientists [1], has initiated intensive attention in the development of mesoporous silica materials and their applications in research and industry [2-14]. Afterwards, a range of highly ordered mesoporous silica materials such as SBA-15 and KIT-6 have been created in 1998 and 2003, respectively [15,16]. The unique physicochemical properties of these materials (such as excellent thermostability and high specific surface areas) make them suitable supports for catalysts that are operable at high temperatures. Among the relevant high-temperature reactions, the catalytic $\mathrm{CO}_{2}$ (dry) reforming of methane (DRM) is an interesting process that has recently attracted substantial attention due to its environmental and economic benefits [17]. DRM converts two atmospheric pollutant greenhouse gases $\left(\mathrm{CH}_{4}\right.$ and $\left.\mathrm{CO}_{2}\right)$ into the versatile intermediate product syngas $\left(\mathrm{CO}+\mathrm{H}_{2}\right)$, as is shown in Equation (1) [18-24]. Syngas can be used for the manufacturing of several substantial high-value-added materials such as synthetic fuels and methanol [25-27]:

$$
\mathrm{CO}_{2(\mathrm{~g})}+\mathrm{CH}_{4(\mathrm{~g})} \rightleftharpoons 2 \mathrm{CO}_{(\mathrm{g})}+2 \mathrm{H}_{2(\mathrm{~g})}\left(\Delta \mathrm{H}^{\circ}=59 \mathrm{kCal} / \mathrm{mol}\right)
$$

Nickel-based catalysts are typically used in the $\mathrm{CO}_{2}$ reforming of methane due to widespread availability, high activity and low price [28-30]. However, DRM is strongly endothermic and requires high temperatures $\left(>700^{\circ} \mathrm{C}\right)$ [31]. Therefore, sintering of the nickel would be likely to happen if the 
reaction takes place above its Tammann temperature $\left(591^{\circ} \mathrm{C}\right)$ [32]. Among the proposed solutions for this drawback, utilising the confinement consequence of the ordered meso pores in the support material to avoid the Ni particles from sintering is a very attractive option [19,33-36]. Although the ordered mesoporous materials have many distinct advantages, they also have some disadvantages as support for Ni-based catalysts when employed in the $\mathrm{CO}_{2}$ reforming of methane. The greatest drawback of these materials is that they have small pores, which are not able to provide sufficient space for the reactants with an adequate number of $\mathrm{Ni}$ active centres to drive the reaction [27,36-39]. As a result, the catalytic capability of $\mathrm{Ni}$ catalysts supported on these materials can be negatively influenced. A range of approaches has been developed to overcome this obstacle. Optimising the pore size and the development of hierarchical porous materials including different pore size systems have received special attention in recent years [9-14,37,38,40-53]. This is because the hierarchical porous structure of the silica supports can not only increase the mass transport of the reactants to the Ni active sites, but also the mesoporous matrix hinders the thermal sintering of the Ni particles by the confinement effect [24,54-56].

Although specific consideration has been paid to the development of hierarchical porous materials, the role of the pore size and the thickness of the pore walls of the catalyst support on the activity of nickel for the $\mathrm{CO}_{2}$ reforming of methane has yet to be addressed. For this purpose, this work focuses specifically on the correlation between the pore properties of a series of mesoporous supports (including tri-modal porous silica (TMS), mesostructured cellular foam (MCF), MCM-41, KIT-6 and SBA-15) and the catalytic activity of the nickel supported on these materials in the $\mathrm{CO}_{2}$ reforming of methane.

\section{Results and Discussion}

\subsection{Catalytic Tests}

A series of the Ni-based nanocatalysts over various porous siliceous supports, namely SBA-15, TMS, KIT- $6, \mathrm{MCF}$ and MCM-41 were studied for the $\mathrm{CO}_{2}$ reforming of methane. The methane and $\mathrm{CO}_{2}$ conversions as a function of time on stream (TOS) obtained are compared in Figure 1.

To discover the role of support on activity and stability of catalysts, the catalytic performance of Ni supported on different ordered mesoporous silicates in DRM which have been reported in the literature along with the catalysts tested in this study is summarised in Table 1. Due to variances in preparation method, $\mathrm{Ni} \%$ and reaction conditions such as gas hour space velocity (GHSV), pressure and temperature, it is difficult to compare support performances precisely. However, in this Table, the initial and final $\mathrm{CH}_{4}$ conversion (\%) of $\mathrm{CO}_{2}$ reforming of methane are compared for DRM reaction which reported at ambient pressure and $700{ }^{\circ} \mathrm{C}$ over catalysts those were prepared via impregnation method. 


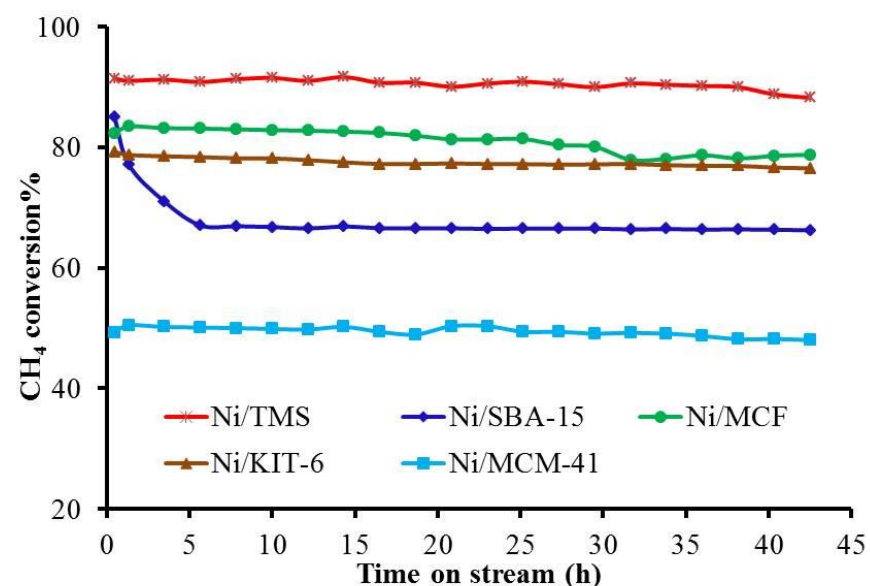

(a)

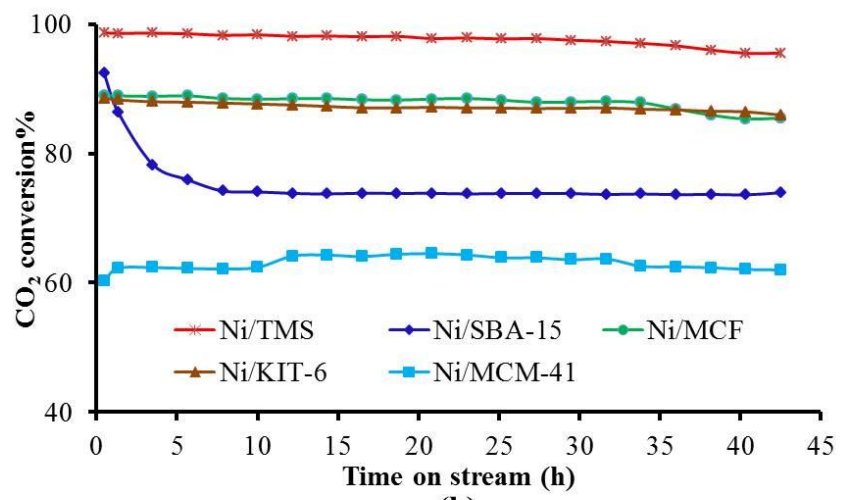

(b)

Figure 1. Conversion of (a) $\mathrm{CH}_{4}$ and (b) $\mathrm{CO}_{2}$ over $\mathrm{Ni} / \mathrm{SiO}_{2}$ catalysts (Reaction conditions: Temperature $=700{ }^{\circ} \mathrm{C} ; \mathrm{CO}_{2}: \mathrm{CH}_{4}=1.0 ; \mathrm{GHSV}=5.2 \times 10^{4} \mathrm{mLg}^{-1} \mathrm{~h}^{-1} ; \mathrm{TOS}=43 \mathrm{~h}$ ).

Table 1. Initial and final $\mathrm{CH}_{4}$ conversion (\%) of DRM at ambient pressure and $700{ }^{\circ} \mathrm{C}$ over Ni supported on different ordered mesoporous silicates those were prepared impregnation method.

\begin{tabular}{cccccc}
\hline Support & $\mathbf{N i} \%$ & GHSV (h-1) & $\begin{array}{c}\text { Initial } \mathrm{CH}_{\mathbf{4}} \\
\text { Conversion (\%) }\end{array}$ & $\begin{array}{c}\text { Final } \mathrm{CH}_{\mathbf{4}} \text { Conversion } \\
\mathbf{( \% )} \text { (Time on Stream) }\end{array}$ & Ref. \\
\hline TMS & 11.8 & $5.2 \times 10^{4}$ & 91.4 & $88.2(44 \mathrm{~h})$ & This work \\
SBA-15 & 11.8 & $5.2 \times 10^{4}$ & 85.1 & $66.2(44 \mathrm{~h})$ & This work \\
MCF & 11.8 & $5.2 \times 10^{4}$ & 82.3 & $78.7(44 \mathrm{~h})$ & This work \\
KIT-6 & 11.8 & $5.2 \times 10^{4}$ & 79.2 & $76.5(44 \mathrm{~h})$ & This work \\
MCM-41 & 11.8 & $5.2 \times 10^{4}$ & 49.3 & $48.0(44 \mathrm{~h})$ & This work \\
SBA-15 & 10 & $1.2 \times 10^{4}$ & $\sim 52$ & $\sim 45(11 \mathrm{~h})$ & {$[57]$} \\
SBA-15 & 5 & $2.25 \times 10^{4}$ & $\sim 75$ & $\sim 60(100 \mathrm{~h})$ & {$[34]$} \\
SBA-15 & 10 & $2.4 \times 10^{4}$ & $\sim 82$ & $\sim 78(4 \mathrm{~h})$ & {$[58]$} \\
SBA-15 & 10 & $1.2 \times 10^{4}$ & $\sim 53$ & $\sim 51(5 \mathrm{~h})$ & {$[59]$} \\
SBA-15 & 7.5 & $2.25 \times 10^{4}$ & $\sim 74$ & $\sim 30(50 \mathrm{~h})$ & {$[60]$} \\
SBA-15 & 5 & N/A & $\sim 79$ & $\sim 78(4 \mathrm{~h})$ & {$[61]$} \\
KIT-6 & 12 & $2.0 \times 10^{4}$ & $\sim 47$ & N/A & {$[62]$} \\
MCM-41 & 5 & $2.25 \times 10^{4}$ & $\sim 79$ & $75(10 \mathrm{~h})$ & {$[34]$} \\
MCM-41 & 5 & N/A & $\sim 76$ & & {$[63]$} \\
\hline
\end{tabular}

Although all catalysts had the same composition $\left(\mathrm{Ni} / \mathrm{SiO}_{2}\right)$, they showed significant differences in catalytic activity, as illustrated in Figure 1 and Table 1 . As seen in Figure 1 and Table 1, the shape and size of pores of support have an important effect on both, the activity and the stability of Ni catalysts. Ni supported on TMS, SBA-15 and MCF supports exhibited higher initial catalytic activity arising 
from the higher accessibility of the Ni active sites. On the other hand, Ni supported on the ordered mesoporous silicas (SBA-15, KIT-6 and MCM-41) showed higher stability, which can be attributed to the higher sintering and coking resistance of catalyst due to the confinement effect of $\mathrm{Ni}$ particles inside silica pores $[33,34,36,38,64]$.

This observation indicates that the morphology and pore structure of the supports significantly affected the catalytic activity and stability. Among the catalysts tested in this work and reported in the literature, the Ni/TMS catalyst showed the highest activity and the most stable catalytic performance. The reason for the high activity of the Ni/TMS catalyst has been explained in an earlier report by the authors [24]. It was found that the existence of 2 nd and 3rd mode pores in TMS support provided more available active $\mathrm{Ni}$ sites to $\mathrm{CH}_{4}$ and $\mathrm{CO}_{2}$ gases compare to other silicate supports. The high accessible active sites in TMS support can lead to the high activity observed for Ni supported on this support [24].

On the contrary, the Ni/MCM-41catalyst showed relatively poor performance among all the catalysts in the $\mathrm{CO}_{2}$ reforming of methane. This observation created a question as to why Ni supported on a well-ordered mesoporous material (MCM-41) showed a significantly lower activity compared to Ni supported on SBA-15, KIT-6, TMS and MCF. The low activity of the Ni/MCM-41 catalyst compared with the Ni catalysts supported on classic ordered mesoporous silica supports has also been widely reported in the literature $[34,36,39,63-66]$. Therefore, the properties of the catalysts were carefully analysed to elucidate the reason for this interesting behaviour.

\subsection{Nitrogen Adsorption-Desorption}

Figure 2 shows pore size distribution curves and $\mathrm{N}_{2}$ adsorption-desorption isotherms of the different silica materials. It can be seen from Figure 2a that the ordered mesoporous materials SBA-15, KIT-6 and MCM-41 show narrow pore size distributions, centred at $7.3 \mathrm{~nm}, 6.3 \mathrm{~nm}$ and $2.6 \mathrm{~nm}$, respectively. In contrast, the pore size distribution for MCF sample showed broad peaks centred around $18.9 \mathrm{~nm}$ and $111.0 \mathrm{~nm}$. The pore size distribution curve of TMS showed three characteristic peaks at $8.1 \mathrm{~nm}, 24.6 \mathrm{~nm}$ and $89.3 \mathrm{~nm}$. A summary of the results obtained from the $\mathrm{N}_{2}$ adsorption-desorption measurements is reported in Table 2. The following order of BET surface areas was observed for the different materials: MCM-41 > KIT-6 > SBA-15> TMS > MCF. The average pore size decreases in the following order: TMS $>$ MCF $>$ SBA-15 $>$ KIT- $6>$ MCM-41. Table 2 shows that the average pore sizes of all the siliceous materials were located in the size range of $3.75-22.66 \mathrm{~nm}$, and are therefore classified as mesopores according to the IUPAC definition [67].

Table 2. Textural properties of the silica materials in $\mathrm{Ni} / \mathrm{SiO}_{2}$ catalysts.

\begin{tabular}{|c|c|c|c|}
\hline & BET Surface Area $\left(\mathrm{m}^{2} / \mathrm{g}\right)^{a}$ & Average Pore Size $(\mathrm{nm})^{b}$ & Pore Volume $\left(\mathrm{cm}^{3} / \mathrm{g}\right)^{\mathrm{c}}$ \\
\hline MCM-41 & 1029 & 3.75 & 0.96 \\
\hline KIT-6 & 902 & 5.75 & 1.18 \\
\hline SBA-15 & 659 & 9.69 & 1.60 \\
\hline TMS & 599 & 22.66 & 1.56 \\
\hline MCF & 225 & 19.30 & 1.30 \\
\hline Ni/MCM-41 & 948 & 2.92 & 0.64 \\
\hline Ni/KIT-6 & 463 & 4.04 & 0.43 \\
\hline Ni/SBA-15 & 460 & 7.66 & 0.88 \\
\hline Ni/TMS & 503 & 20.11 & 1.32 \\
\hline $\mathrm{Ni} / \mathrm{MCF}$ & 228 & 19.13 & 1.08 \\
\hline
\end{tabular}

${ }^{a}$ BET surface area. ${ }^{b}$ Desorption average pore diameter $\left(4 \mathrm{~V} / \mathrm{A}\right.$ by BET) ${ }^{\mathrm{c}}$ Single point desorption.

As can be seen from the $\mathrm{N}_{2}$ adsorption-desorption curves in Figure $2 \mathrm{~b}$, the materials demonstrate hysteresis loops with different shapes. The ordered mesoporous materials MCM-41, KIT-6 and SBA-15 exhibit $\mathrm{H} 1$ hysteresis loops, which is typical of materials with independent pores [67]. The existence of an H4 hysteresis loop for the MCF sample provides evidence of narrow slit-like pores $[24,67]$. On the 
other hand, TMS showed a non-uniform pore structure, with an $\mathrm{H} 3$ hysteresis loop at low relative pressures $\left(\mathrm{P} / \mathrm{P}_{\mathrm{o}}\right)$ created by the capillary condensation of $\mathrm{N}_{2}$ molecules highlighting the presence of cage-like mesopores, while the $\mathrm{H} 2$ hysteresis loop at $\mathrm{P} / \mathrm{P}_{\mathrm{o}}=0.81$ is a sign of secondary interstitial multicellular pores [24]. In spite of these differences, it is clear that all materials exhibited type IV isotherms, demonstrating that all of the samples are mesoporous in nature.

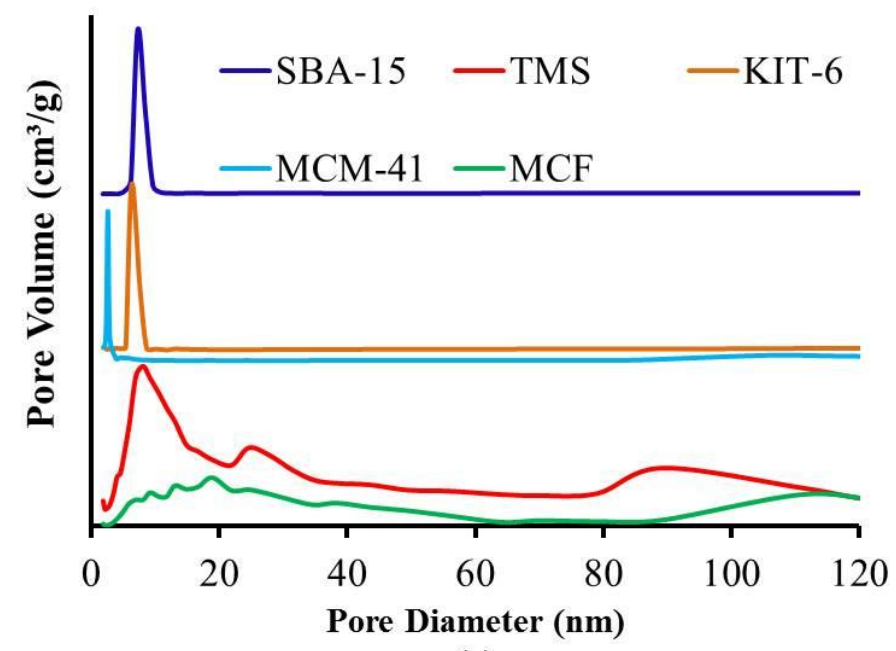

(a)

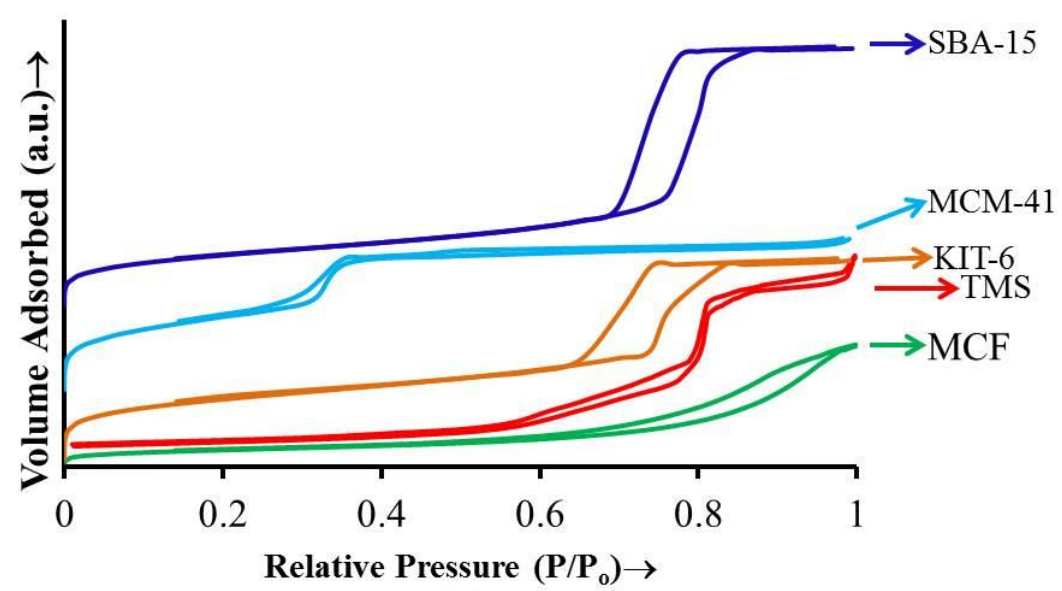

(b)

Figure 2. (a) Pore size distribution curves and (b) $\mathrm{N}_{2}$ adsorption-desorption isotherms of the silica materials.

\subsection{SAXS Characterisation}

The small-angle XRD patterns of the synthesised silica materials are displayed in Figure 3. The observed $2 \theta$ values centred at $\sim 0.9^{\circ}, \sim 1.5^{\circ}$ and $\sim 1.8^{\circ}$ in the patterns of SBA-15 and TMS samples correspond to the (100), (110) and (200) reflections, respectively, associated with p6mm hexagonal structures $[15,68,69]$. MCM-41 also gives Bragg peaks at the $2 \theta$ value of $2.3^{\circ}, 4.0^{\circ}$ and $4.6^{\circ}$ which can be indexed to (100), (110) and (200) reflections, respectively, associated with a p6mm hexagonal structure [70-72]. For KIT-6, three peaks are indexed as (211), (220) and (420) reflections [16]. On the contrary, no such order was found for the MCF material, which can be attributed to the absence of an ordered porous structure or the poor distribution of the porous structure. These observations are in line with the findings from pore size distribution (Figure $2 \mathrm{a}$ ) and $\mathrm{N}_{2}$ adsorption-desorption isotherm studies (Figure 2b). 


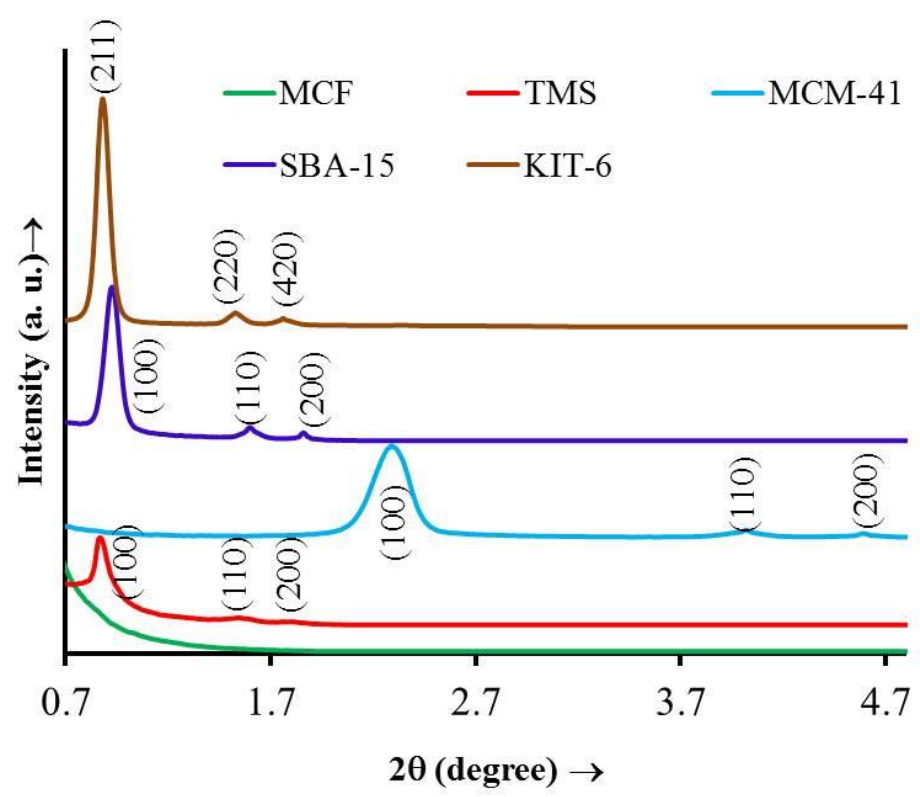

Figure 3. Small angle $X$-ray scattering patterns of the silica materials.

\subsection{XRD Characterisation}

The wide-angle XRD patterns of samples before and after reduction are presented in Figure 4. The diffraction peaks at $2 \theta=37.3^{\circ}, 43.3^{\circ}, 62.9^{\circ}, 75.4^{\circ}$ and $79.4^{\circ}$ were detected for all samples before reduction, corresponding to the (111), (200), (220), (311) and (222) planes of cubic NiO, respectively (PDF card \# 78-0643).

It can be observed from Figure $4 \mathrm{~b}$ that XRD patterns of the reduced catalysts do not show any peaks for nickel oxide. The diffraction peaks can be seen at $2 \theta$ values of $44.5^{\circ}, 51.8^{\circ}$ and $76.4^{\circ}$, which assigned to the (111), (200) and (220) planes of cubic phase of metallic $\mathrm{Ni}^{0}$ (PDF card \# 87-0712).
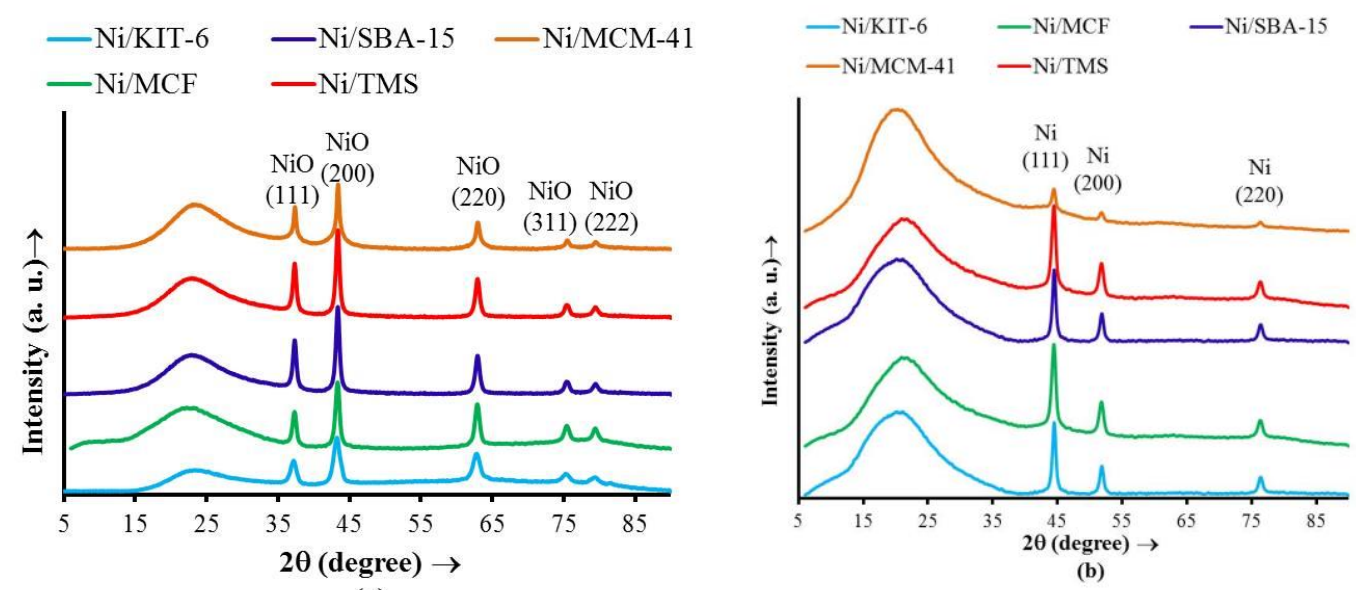

(a)

Figure 4. X-ray patterns of (a) calcined and (b) reduced $\mathrm{Ni} / \mathrm{SiO}_{2}$ catalysts.

\subsection{XPS Characterisation}

XPS was used to analyse the surface composition and elemental valence states of the calcined catalysts before reduction. Ni $2 p_{3 / 2}$ and Ni $2 p_{1 / 2}$ XPS spectra of the catalysts are illustrated in Figure $5 \mathrm{a}$. The Ni $2 p_{3 / 2}$ peaks in all samples are centred at a binding energy of $854.0 \mathrm{eV}$ with a shoulder at 856.0 $\mathrm{eV}$ and a satellite peak at $861.1 \mathrm{eV}$ which corresponds to $\mathrm{NiO}$ [20,73-75] rather than metallic nickel [76]. In addition, the $\mathrm{Ni} 2 \mathrm{p}_{1 / 2}$ peaks in all samples are present at a binding energy of $872.0 \mathrm{eV}$, providing further evidence of the presence of $\mathrm{NiO}$ [20,73-75]. As shown in Figure 5b, the $\mathrm{Si} 2 \mathrm{p}$ binding energy 
of all catalysts show a characteristic peak at $103.3-103.6 \mathrm{eV}$ attributed to $\mathrm{SiO}_{2}$ [75], suggesting no interaction of NiO particles with support. From the XRD patterns and XPS profiles of these catalysts, it can be concluded that there were no obvious chemical interactions between the nickel and its support, and any significant difference in electronic structure among all catalysts.

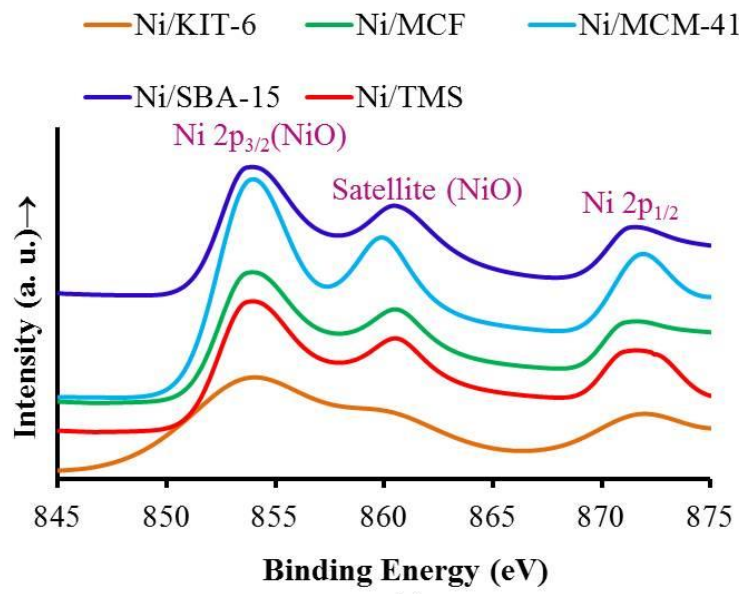

(a)

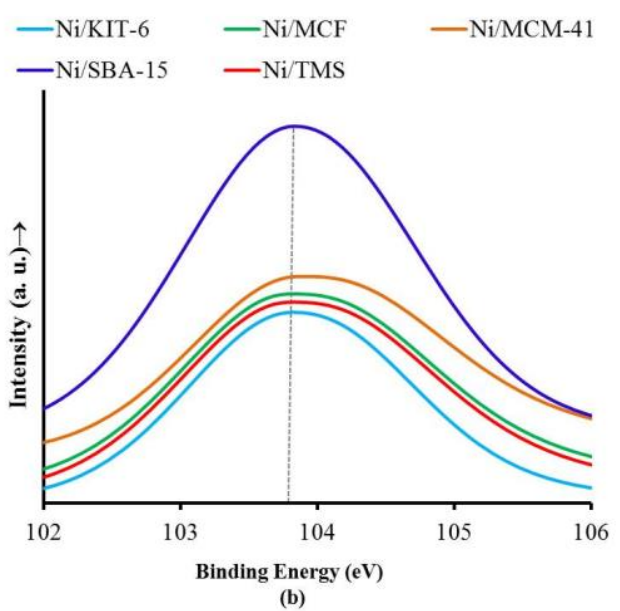

(b)

Figure 5. (a) Ni 2p and (b) Si 2p XPS spectra of the $\mathrm{Ni} / \mathrm{SiO}_{2}$ catalysts.

The percentage of $\mathrm{Ni}$ on the surface of the reduced $\mathrm{Ni} / \mathrm{SiO}_{2}$ materials were evaluated using XPS, and the results are shown in Table 3. The amount of Ni on the surface of different catalysts was found to be inversely proportional to the average pore size of the ordered mesoporous silica materials (MCM-41, KIT-6 and SBA-15). As later confirmed by TEM study, the nickel particles can be more easily accommodated within the larger pores of these materials compared to the smaller pores. The smaller pore size of MCM-41 may hinder the dispersion of Ni particles inside the pores. Ni particles can easily infiltrate into the larger mesoporous channels during the impregnation process [34]. However, in the case of Ni/MCF and Ni/TMS catalysts, a different trend was observed. It seems that there was no direct relationship between the $\% \mathrm{Ni}$ in the surface of these materials and their pore size. This is most likely due to their wide range of pore diameters.

Table 3. Atom \% nickel in the surface of reduced Ni catalysts with different supports as determined by XPS.

\begin{tabular}{cccccc}
\hline Support & SBA-15 & KIT-6 & MCM-41 & TMS & MCF \\
\hline $\mathrm{N}$ in surface (atom \%) & 1.1 & 2. 6 & 4.0 & 2.4 & 2.7 \\
\hline
\end{tabular}

\subsection{FTIR Characterisation of the Siliceous Materials}

The FTIR spectra of supports and catalysts in the region between 400 and $4000 \mathrm{~cm}^{-1}$ are presented in Figure 6. No differences were detected in the spectra of the supports (Figure 6a). The FTIR spectra of all supports show infrared absorption peaks at $830-870 \mathrm{~cm}^{-1}, 950-980 \mathrm{~cm}^{-1}$, $1090-1120 \mathrm{~cm}^{-1}, 1600 \mathrm{~cm}^{-1}, 3400 \mathrm{~cm}^{-1}$ and $3750 \mathrm{~cm}^{-1}$, which are assigned to the Si-O-Si bending vibrations, $\mathrm{Si}-\mathrm{OH}$ stretching vibrations of non-bridging oxygen, asymmetric stretching, deformation vibrations of adsorbed water molecules, stretching of adsorbed water molecules and $\mathrm{OH}$ vibrations of free silalon groups $[77,78]$, respectively. 


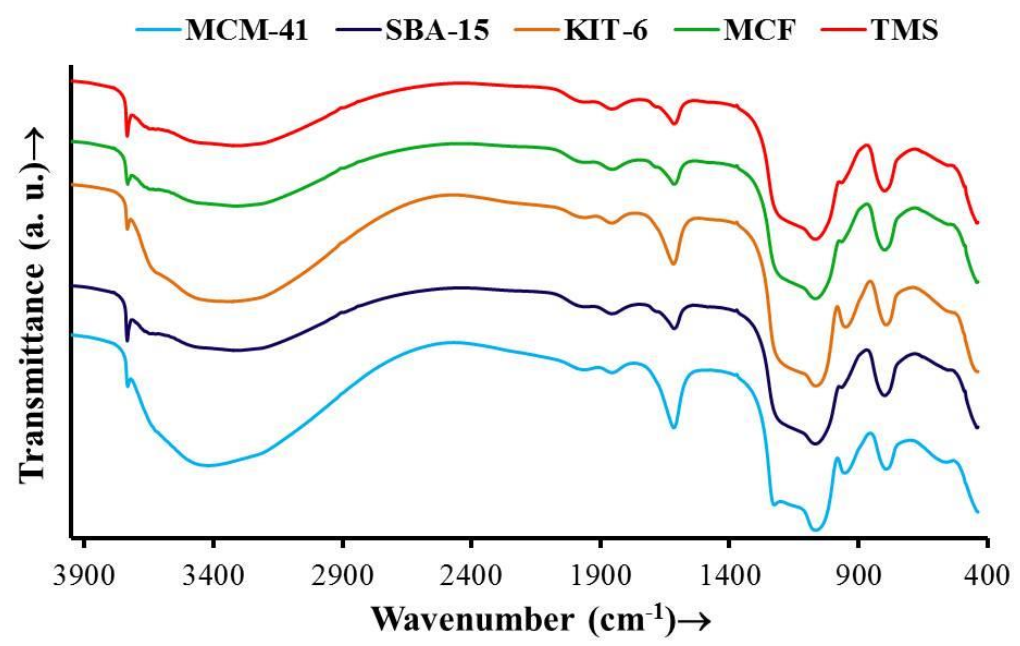

(a)

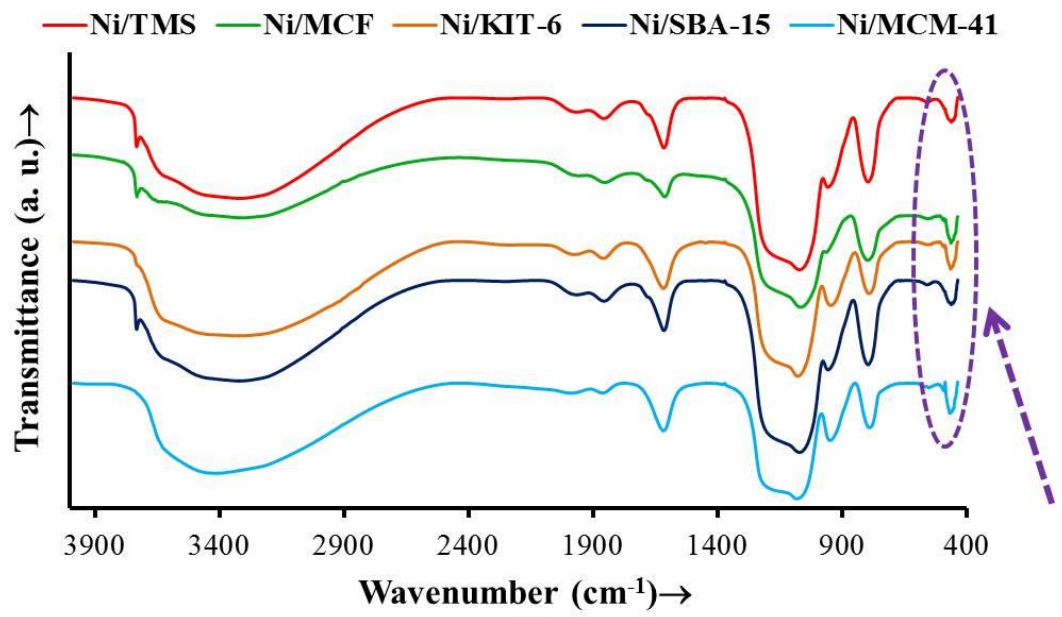

(b)

Figure 6. FTIR spectra of (a) the silica materials and (b) the $\mathrm{Ni} / \mathrm{SiO}_{2}$ catalysts.

The FTIR spectra of the $\mathrm{Ni} / \mathrm{SiO}_{2}$ catalysts are illustrated in Figure $6 \mathrm{~b}$. The addition of Ni into the supports generated a new peak at $482 \mathrm{~cm}^{-1}$ (marked by a circle), which is attributed to the stretching vibration of bulk $\mathrm{NiO}$ [78]. With the exception of the $\mathrm{NiO}$ peak, all FTIR spectra of the $\mathrm{Ni} / \mathrm{SiO}_{2}$ catalysts were found to be very similar to that of the pure supports, indicating that there was no noticeable chemical interaction between the nickel and the support. This result is in line with the XRD and XPS results. However, it should also be noted that the narrow peak at $3750 \mathrm{~cm}^{-1}$ disappeared in the FTIR spectrum of Ni/MCM-41. Thus, it can be concluded that in the case of MCM-41 the addition of NiO led to the fixing of the free silanol groups in the $\mathrm{Si}-\mathrm{O}$ network, impeding the $\mathrm{OH}$ vibrations of free silanol groups [77] due to the presence of disordered narrow pore networks.

\subsection{TEM of the Siliceous Materials}

Figure 7 presents high-resolution TEM (HRTEM) images of the synthesised siliceous materials. The microstructure of TMS was discussed in detail in an earlier report by the authors [24]. From the HRTEM images of the MCM-41, KIT-6 and SBA-15, it can be seen that the long ordered parallel pores have been retained after the high-temperature calcination. The pore sizes of the siliceous materials were estimated by TEM analysis using ImageJ software. The average pore size of MCM-41, KIT- 6 and SBA-15 were $3.3 \mathrm{~nm}, 6.9 \mathrm{~nm}$ and $9.4 \mathrm{~nm}$, respectively. These observations are in line with the results from the $\mathrm{N}_{2}$ adsorption-desorption study (Table 1). MCF demonstrated an entirely different texture compared 
with the above materials, having uniform cells with an average diameter of $7.3 \mathrm{~nm}$. The average cell diameter of the MCF synthesised under the present conditions is smaller than what has been reported in the literature (MCFs with cell diameters of $22 \mathrm{~nm}$ and $32 \mathrm{~nm}$ ) [79]. It can be seen from Figure 7 that there are interconnected pores in the $\mathrm{MCF}$, which could be the reason for their broad distribution of pores in Figure 2a.

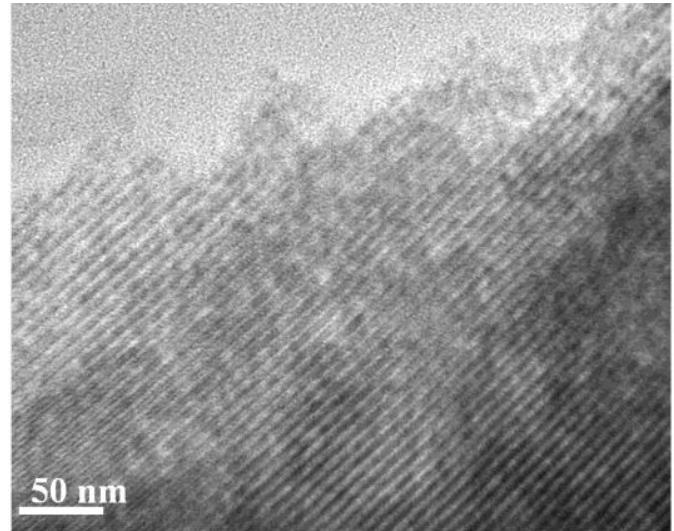

SBA-15

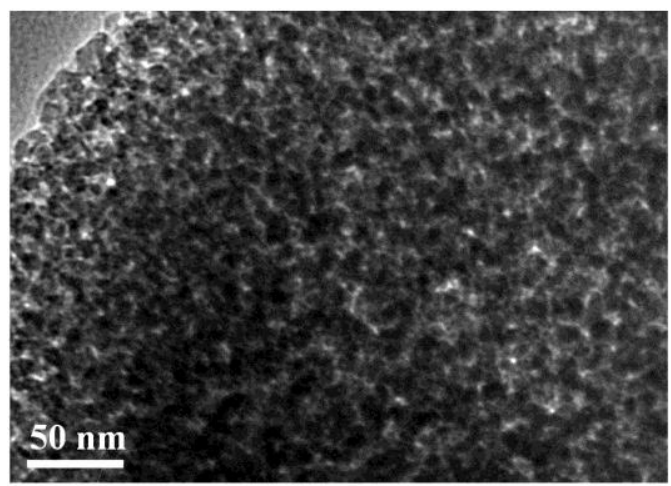

MCF

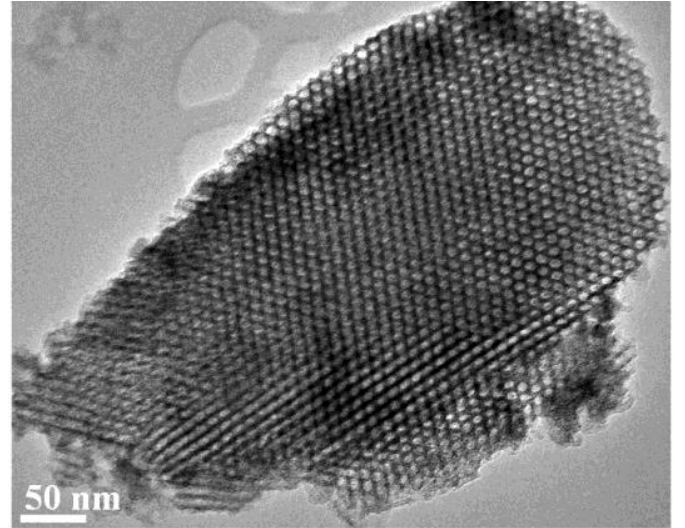

KIT-6

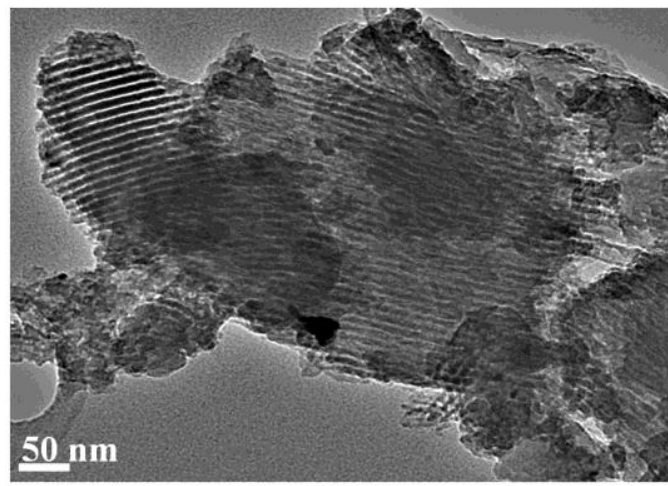

TMS

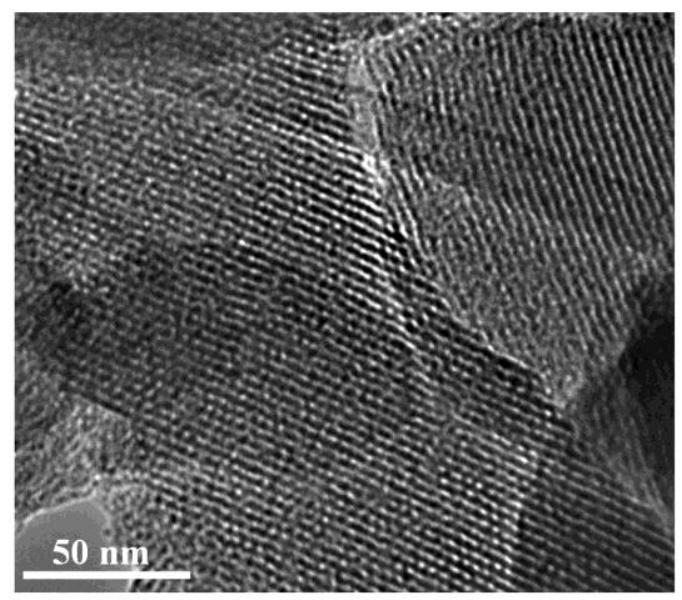

MCM-41

Figure 7. TEM images of the synthesised siliceous materials.

The TEM images of the reduced $\mathrm{Ni} / \mathrm{SiO}_{2}$ materials are presented in Figure 8. The average pore wall thickness and particle size distribution of metal in these materials were determined by evaluating ca. 100 particles using ImageJ software and the results are shown in Figure 9. The following orders were observed for catalysts with different supports:

The order of average Ni particle sizes: Ni/MCF $>$ Ni/MCM-41 $>$ Ni/KIT-6 $>$ Ni/TMS $\approx$ Ni/SBA-15. 
The order of average pore wall thicknesses: Ni/MCF $>$ Ni/KIT-6 $>\mathrm{Ni} / \mathrm{TMS} \approx \mathrm{Ni} / \mathrm{SBA}-15>>$ $\mathrm{Ni} / \mathrm{MCM}-41$.

Considerable differences were observed in the Ni nanoparticle size distribution patterns for the different catalysts, owing to the pore structures of supports. In the case of Ni/SBA-15, Ni/TMS and $\mathrm{Ni} / \mathrm{MCF}$ catalysts some large nanoparticles were formed outside of the pores of these supports. However the majority of Ni particles have sizes that are smaller than these pores. The existence of these small-sized Ni particles provides evidence that these particles were trapped in the pore channels of the support materials. Such confinement of nickel particles has previously been shown to increase the thermal stability of Ni nanoparticles [80-89]. In the present work, it is concluded that the confinement effect prevented the occurrence of any observable sintering, even though the reduction temperature $\left(700^{\circ} \mathrm{C}\right)$ was much higher than the Tammann temperature of nickel $\left(591^{\circ} \mathrm{C}\right)$ [32].

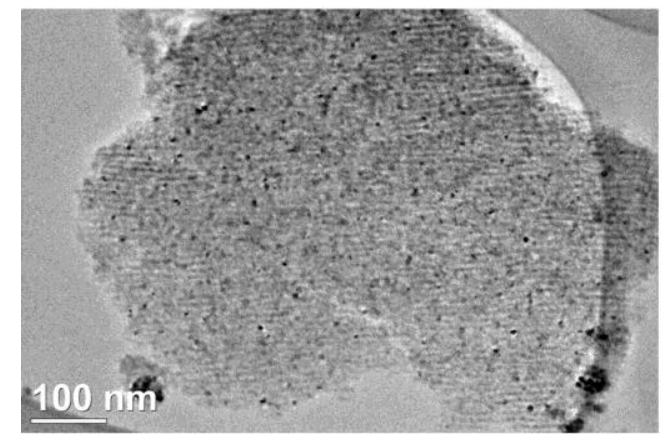

Ni/SBA-15

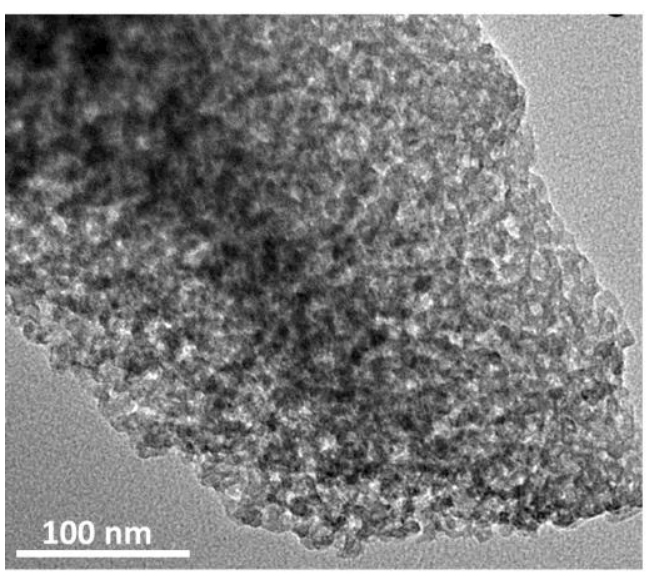

Ni/MCF

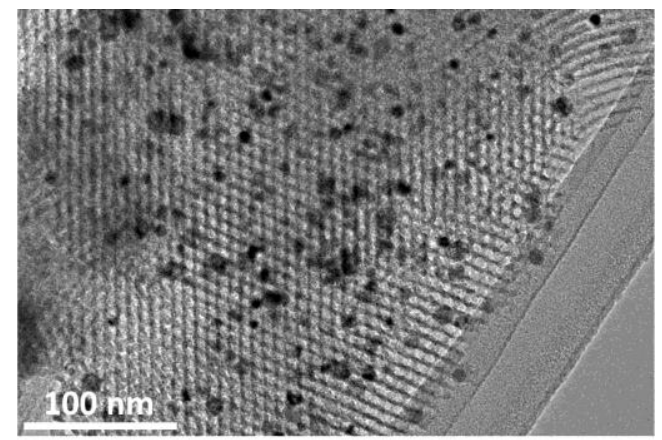

Ni/KIT-6

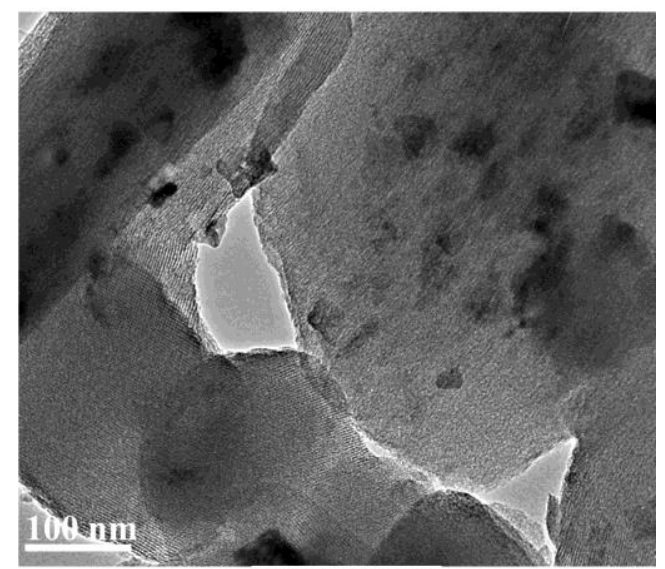

Ni/MCM-41

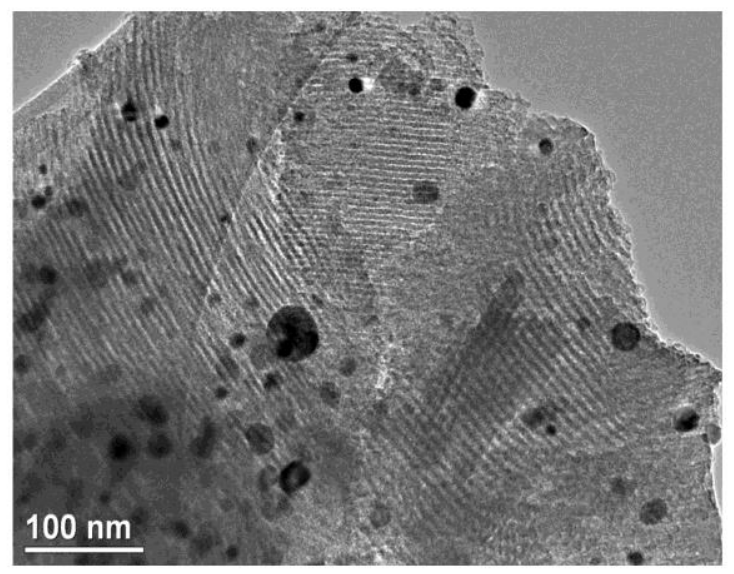

Ni/TMS

Figure 8. TEM images of the $\mathrm{Ni} / \mathrm{SiO}_{2}$ catalysts. 
An interesting phenomenon was detected for the Ni particle size distributions for the Ni/MCF, Ni/MCM-41 and Ni/KIT-6. As can be observed in Figure 9, the Ni particles in these materials presented a bimodal size distribution. In these catalysts, a portion of Ni particles has a size smaller than the pore size of their support material, which can be attributed to the confinement effect of pore walls. Besides this, another portion of Ni particles is larger than the pore size of their support materials, indicating that their size was not controlled by the confinement effect of the pore walls. This phenomenon could be explained by the presence of the two distinguishable types of nickel sites on these supports, namely the nickel particles inside and outside of pores of the support materials. It is therefore apparent that the size and position of nickel sites strongly depend on the size and wall thickness of the support material's pores. The ratio of Ni species inside the pores, which can be affected by the confinement effect, significantly depended on the size of the pore of the support. The percentage of inner Ni species was found to increase as the pore size of support increased, as can be expected.
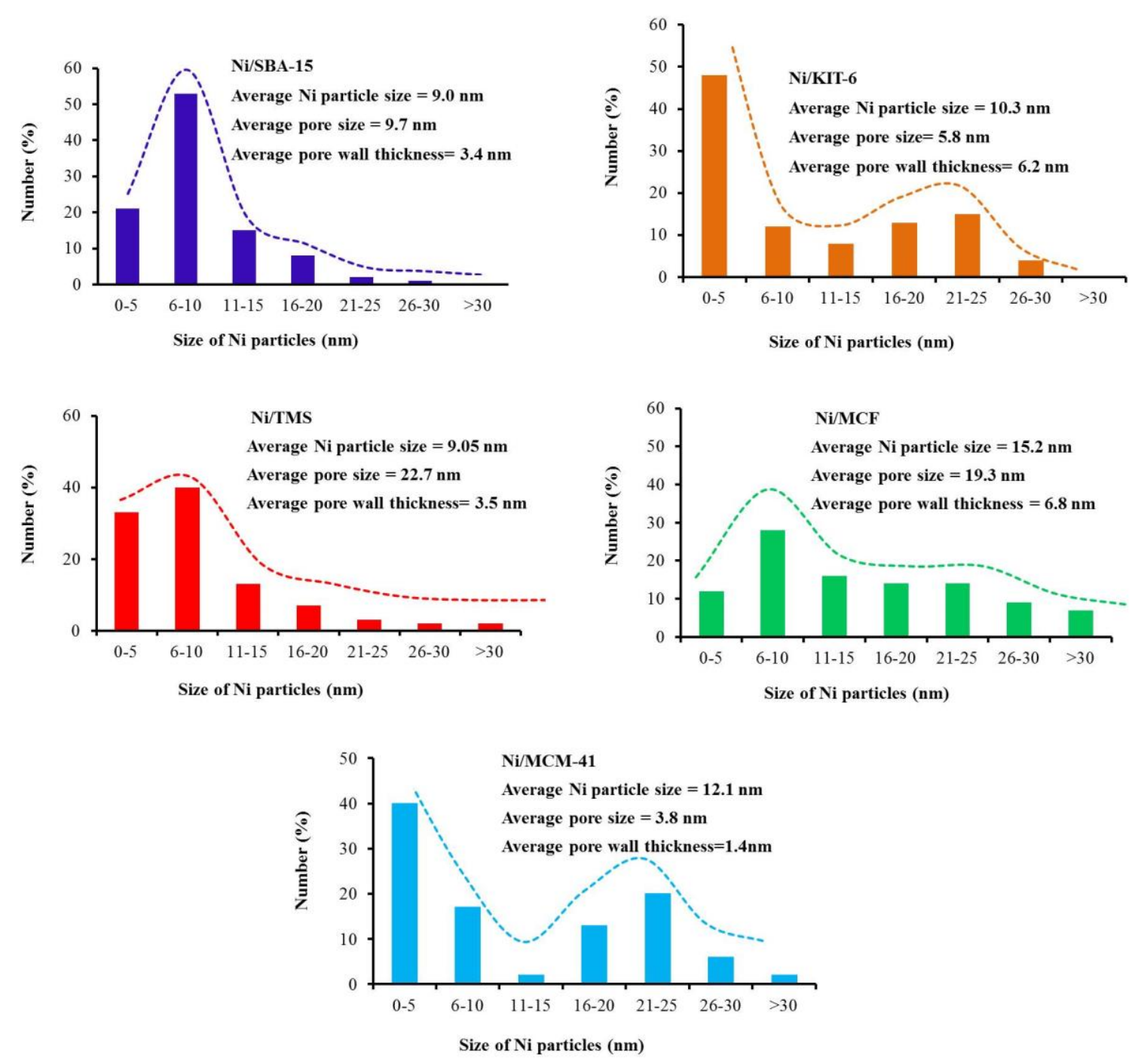

Figure 9. Ni particle size distribution, average Ni particle size, average pore wall thickness and average pore size in the catalysts (average pore size was measured by $\mathrm{N}_{2}$ adsorption-desorption method).

In the case of Ni/MCM-41, the majority of Ni particles have sizes that are larger than the pores of support materials, which means that most of the Ni particles were located outside of these pores. This is most likely due to the narrow channels of MCM-41 (with an average size of $3.8 \mathrm{~nm}$ ) which reduces the amount of nickel nitrate solution that was delivered into the pore channels during the impregnation process [81]. 
As a follow up from closer examination by HRTEM and EDS-mapping (Figure 10), another interesting phenomenon was observed for the Ni/MCM-41 material. It was found that the mechanical strength of the pore walls in MCM-41 is not high enough to effectively prevent the thermal sintering of the Ni particles entrapped inside the porous channel at temperatures higher than the Tammann temperature of nickel [32]. HRTEM investigation showed the majority of nickel particles were located on the outer surface of the MCM-41, which does not seem to be greatly affected by the confinement effect of the pore walls.
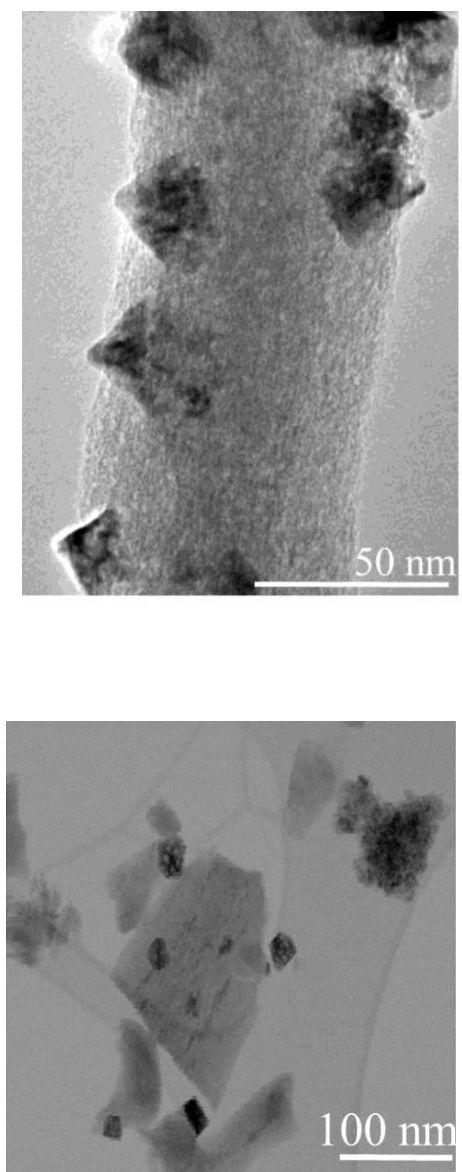

STEM

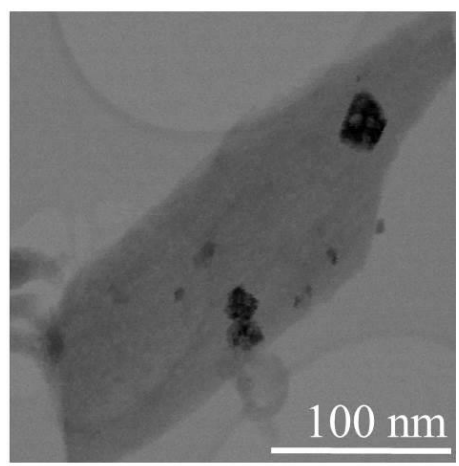

STEM

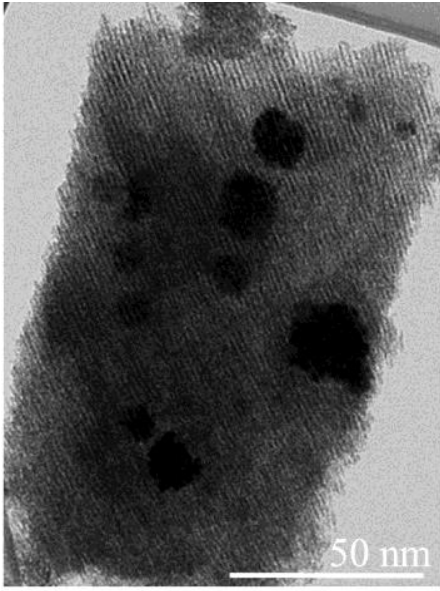

(a)

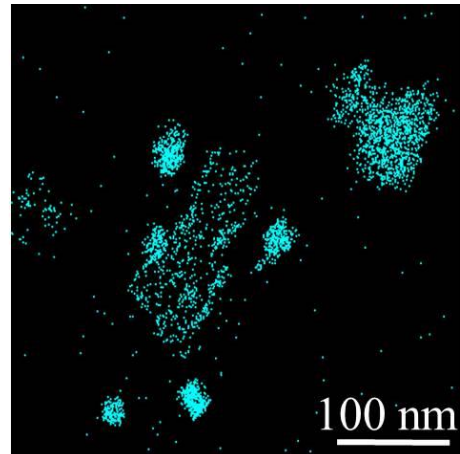

Ni K Series

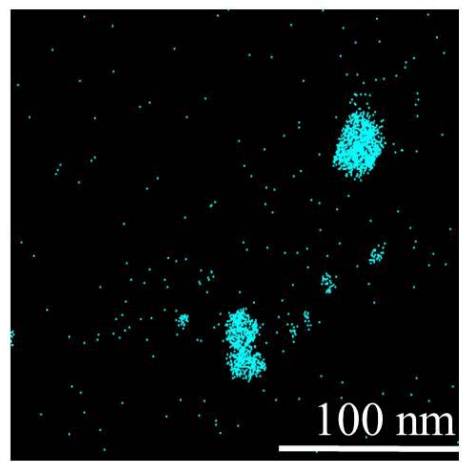

Ni K Series
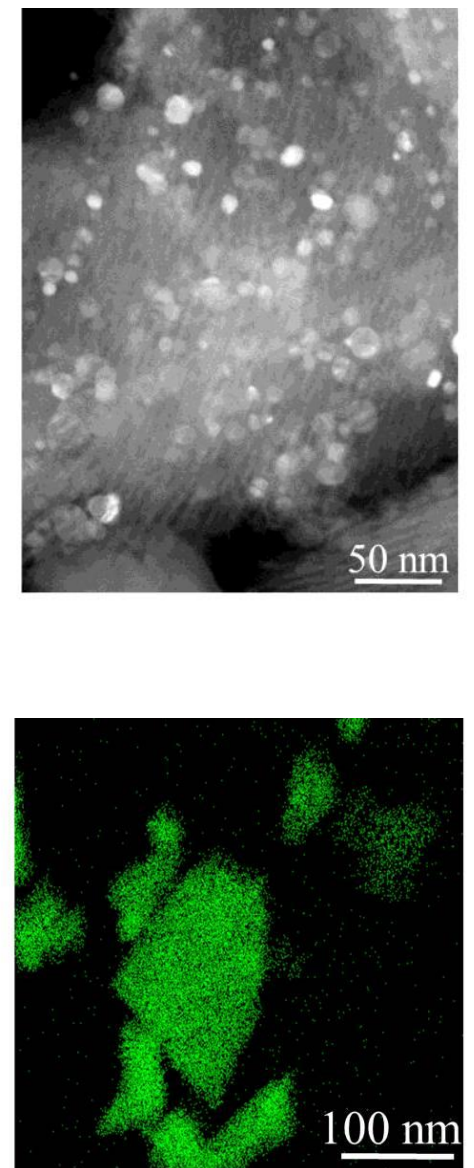

Si K Series

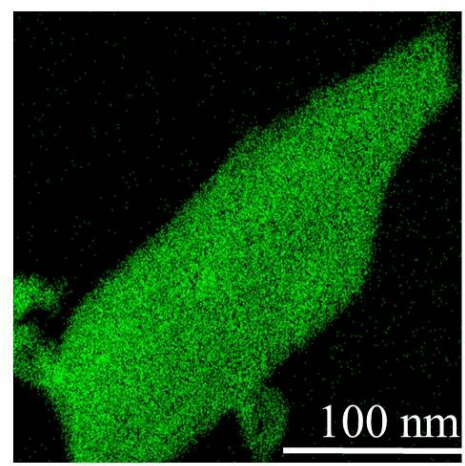

Si K Series

(b)

Figure 10. (a) HRTEM image and (b) HAADF-STEM images and corresponding EDS elemental mapping images of Ni/MCM-41. 
Figure 11 presents high-angle annular dark field scanning transmission electron microscopy (HAADF-STEM) images of Ni particles inside the pores of the ordered supports, namely SBA-15, KIT-6 and MCM-41. HAADF STEM shows atomic number contrast for high scattering angles of the electrons; therefore Ni particles are clearly visible in the Z-contrast image [90]. As proven by HAADF-STEM imaging, although MCM-41 has a smaller pore size compared to SBA-15 and KIT-6 supports, its silica walls were not strong enough to resist the agglomeration of Ni crystals inside the pores during sintering at temperatures higher than the Tammann temperature of nickel [32]. This finding is in line with previous literature data that MCM-41 has the relatively smooth pore wall surfaces as compared to the SBA-15 material [91,92].

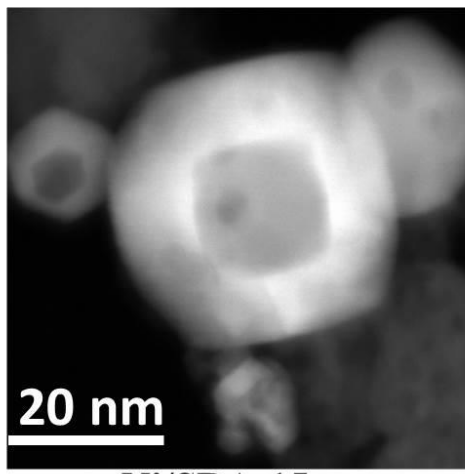

Ni/SBA-15

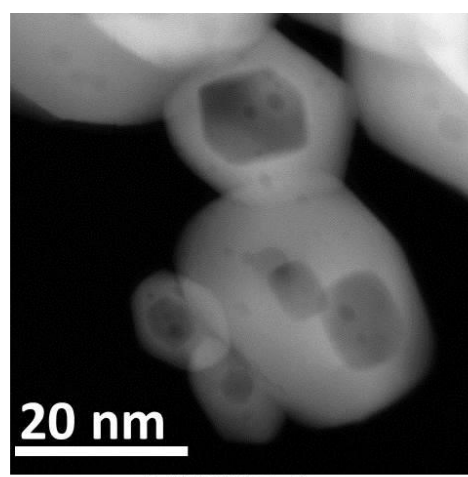

Ni/KIT-6

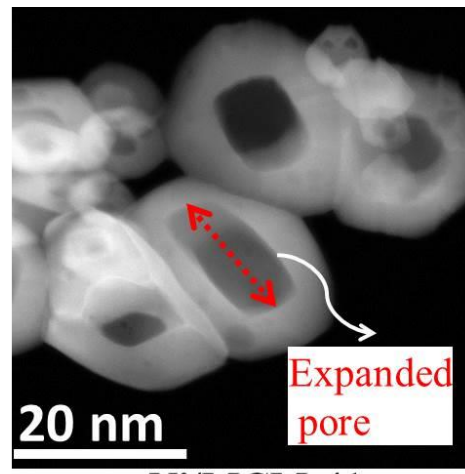

Ni/MCM-41

Figure 11. HAADF-STEM images of Ni particles inside the pores of SBA-15, KIT-6 and MCM-41.

The schematic drawing for this behaviour is presented in Figure 12, which compares the confinement effect on the Ni nanoparticles trapped inside the channels of MCM-41 with those trapped inside the channels of other supports.
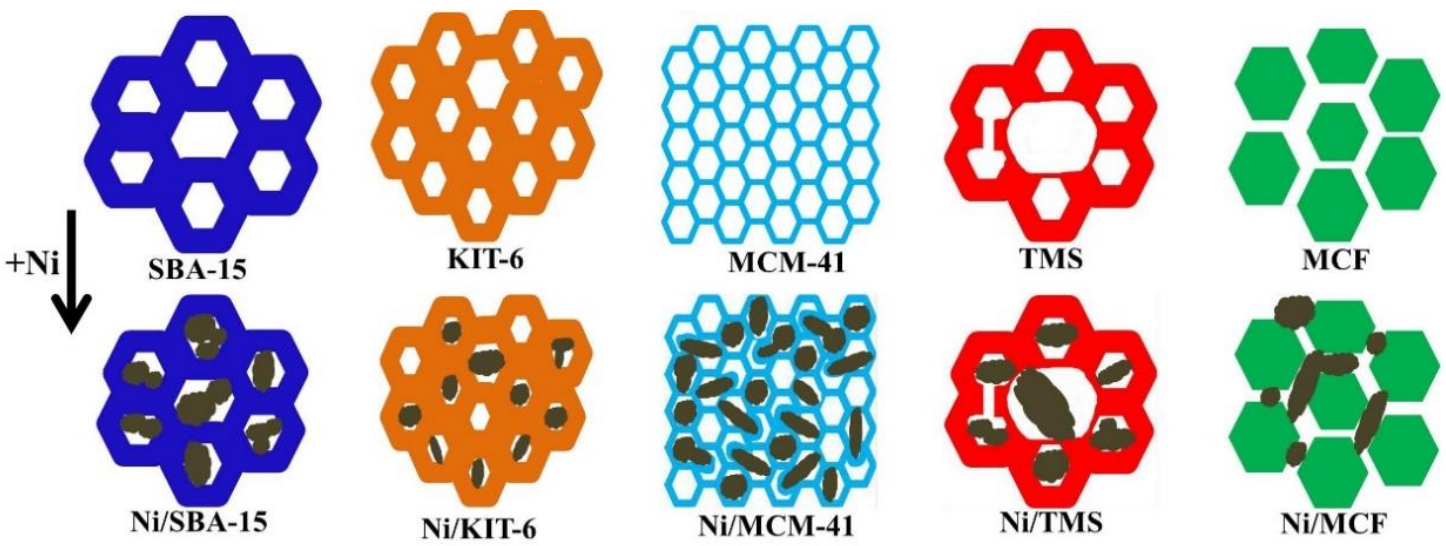

Figure 12. Suggested schematic of the confinement effect on the Ni nanoparticles trapped inside the channels of supports.

Another important observation from the TEM studies is that a large number of the pore mouths were partially filled by the growth of the Ni particles inside the pores of MCM-41. Therefore, the blockage of pores (especially the small pores) can cause a decrease in the amount of accessible Ni sites to gas molecules. It has been shown in the literature that blocking the active sites can be one of the major reasons why Ni/MCM-41 exhibited the lowest activity among the other tested catalysts [93-96].

Based on the obtained results of this work, it is possible to have a clearer view of the effect of the support morphology on the performance of Ni-based porous silica catalysts in the $\mathrm{CO}_{2}$ reforming of methane. The results of FTIR, XRD, SAXS and XPS analyses did not show any distinguishable chemical interaction between the nickel and the supports that were tested in this study. Nevertheless, it was 
clear that the pore size and the thickness of the silica walls greatly influence the amount of accessible $\mathrm{Ni}$ for the reactants and the role of the mesoporous supports in the prevention of metallic Ni particles from sintering through the confinement effect at temperatures higher than the Tammann temperature of nickel. With a particular focus on Ni/MCM-41, it seems that the nickel nitrate precursor solution was not able to transfer smoothly into the narrow channels of MCM-41 during impregnation. Consequently, a large number of Ni particles remained on the external surface of the mesoporous channels, instead of embedding inside the pores of the support. As a result, the bimodal size distribution of nickel particles in Ni/MCM-41 was created. Besides this, the slim walls of MCM-41 are not able to effectively confine the growth of the Ni particles which were able to grow inside the pores of MCM-41 during the thermal sintering at high temperatures. This led to the partial blocking of the pore channels, which limits the availability of Ni sites inside pores to the reactants gases through the pore channels of MCM-41.

\section{Experimental}

\subsection{Synthesis of the Silica Supports}

A family of mesoporous silica structures was synthesised through the hydrothermal assisted sol-gel method. The SBA-15, TMS and MCF materials were prepared via the methods reported previously by the authors [24], while the siliceous KIT-6 [16] and MCM-41 [1,70] materials were prepared according to pioneering procedures reported in the literature.

For the synthesis of MCM-41 hexadecyltrimethylammonium bromide (CTMABr, $\mathrm{C}_{16} \mathrm{H}_{33}\left(\mathrm{CH}_{3}\right)_{3} \mathrm{NBr}$, $364.52 \mathrm{~g} / \mathrm{mol}$, Aldrich, was employed as an ionic surfactant, while a sodium silicate solution (27 wt.\% $\mathrm{SiO}_{2}$, Aldrich) was used as the silicate source.

For the synthesis of the SBA-15, TMS, MCF and KIT-6 support materials triblock copolymer P123 $\left(\mathrm{EO}_{20} \mathrm{PO}_{70} \mathrm{EO}_{20}, 5800 \mathrm{~g} / \mathrm{mol}\right.$, Pluronic P123, Aldrich) was used as a non-ionic surfactant. For these syntheses, 1,3,5-trimethylbenzene (TMB, $\mathrm{C}_{9} \mathrm{H}_{12}, 120.19 \mathrm{~g} / \mathrm{mol}$, Aldrich) and tetraethyl orthosilicate (TEOS, $\mathrm{C}_{8} \mathrm{H}_{20} \mathrm{O}_{4} \mathrm{Si}, 208.33 \mathrm{~g} / \mathrm{mol}$, Aldrich) were used as a swelling agent and a silica source, respectively.

A schematic graphic of the typical synthesis route for the materials is presented in Figure 13.

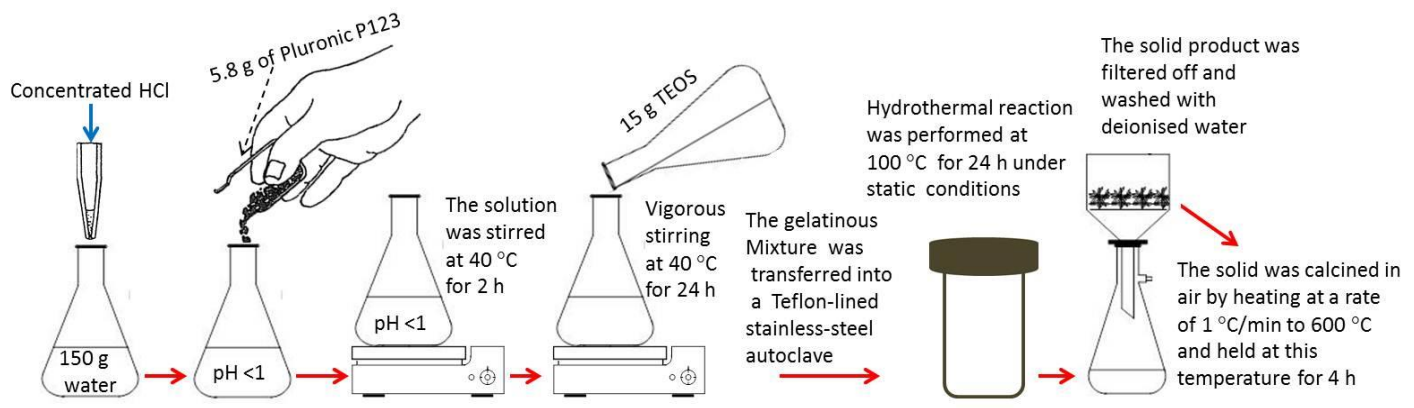

(a)
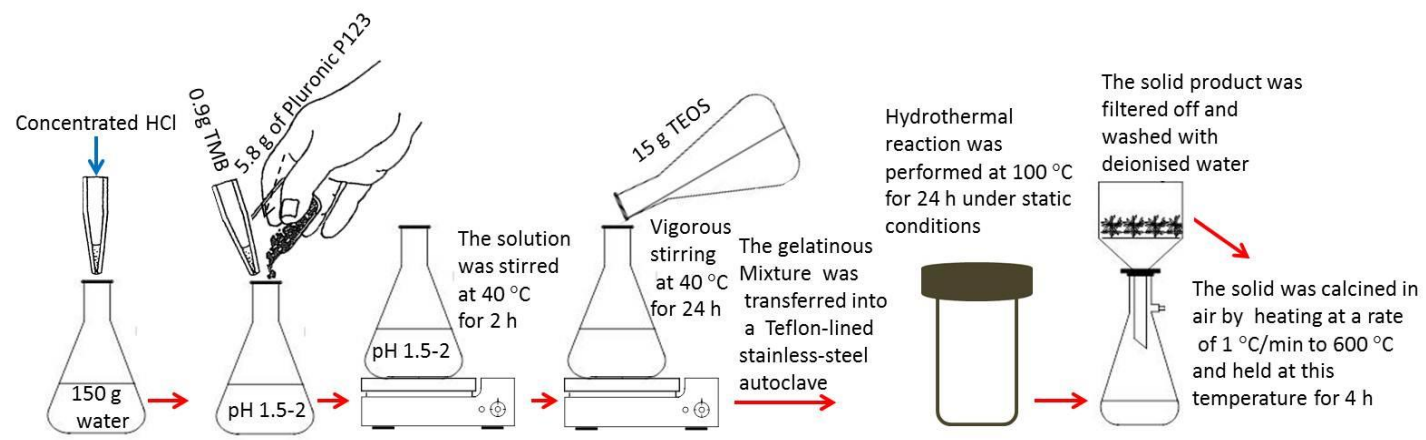

(b)

Figure 13. Cont. 


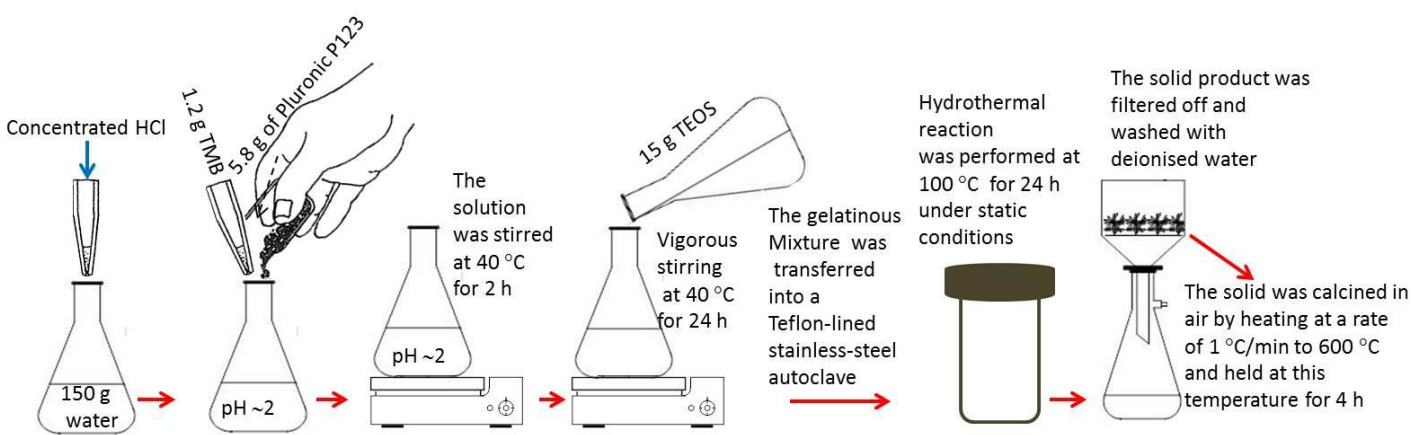

(c)
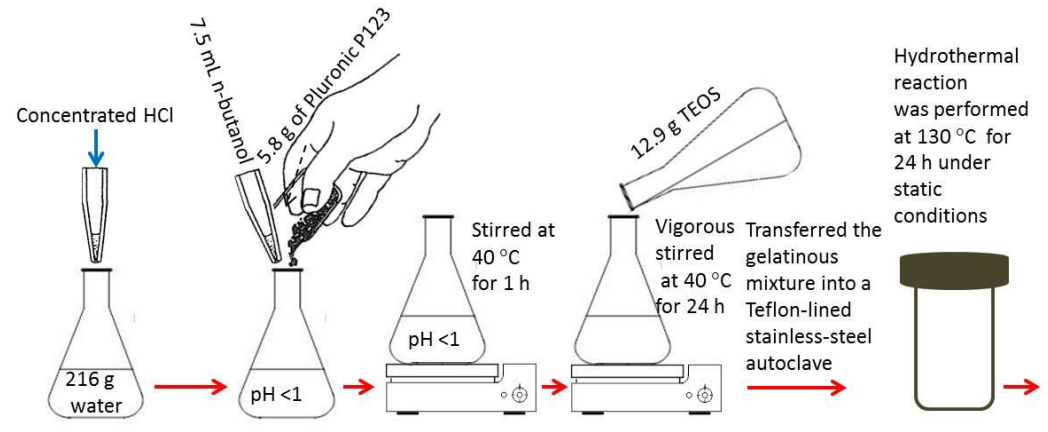

The solid product

was filtered off and

washed with an

ethanol/HCl solution

(50:50)

(d)

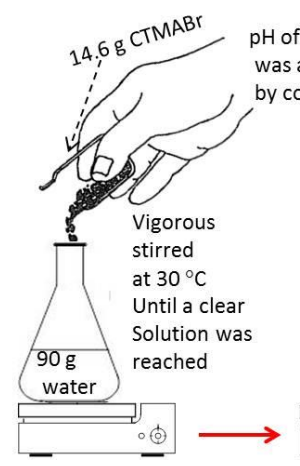

$\mathrm{pH}$ of the mixture
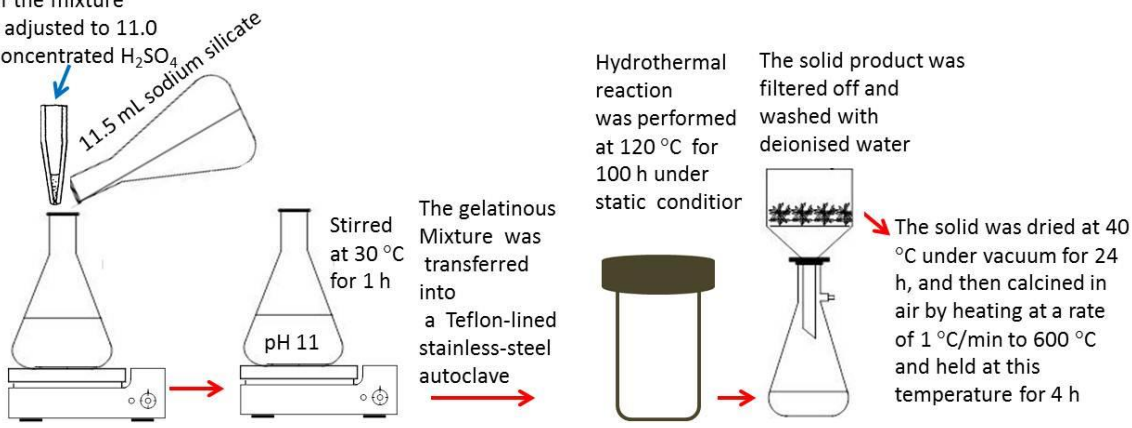

(e)

Figure 13. The schematic illustration of the typical synthesis procedure for the materials: (a) SBA-15,

(b) TMS, (c) MCF, (d) KIT-6 and (e) MCM-41.

\subsection{Synthesis of the Ni Catalysts on the Supports}

The wet impregnation method was employed to prepare the Nickel catalysts supported on the synthesised mesoporous silicas. The required amount of nickel (II) nitrate hexahydrate was dissolved in Milli-Q water while stirring. The siliceous supports were impregnated with this aqueous solution at ambient conditions overnight. The solutions were then dried at $110^{\circ} \mathrm{C}$ overnight and then calcined in air at $600{ }^{\circ} \mathrm{C}$ for $4 \mathrm{~h}$ (with a ramp rate of $5{ }^{\circ} \mathrm{C} / \mathrm{min}$ ). Based on previous studies by the author $[18,19,22-24]$, the composition of the catalysts was kept constant at $15 \mathrm{wt} . \% \mathrm{NiO}(11.8 \mathrm{wt} . \% \mathrm{Ni})$ with respect to silica with the introduction of an appropriate amount of the nickel precursor. For example, $1.84 \mathrm{~g}$ $\mathrm{Ni}\left(\mathrm{NO}_{3}\right)_{2} \cdot \mathrm{H}_{2} \mathrm{O}_{6}$ was added to $5.00 \mathrm{~g}$ the synthesised mesoporous silicas.

\subsection{Characterisation Techniques}

BET surface areas and $\mathrm{N}_{2}$ adsorption-desorption isotherms of the synthesised materials were determined using an ASAP 2020 instrument Micromeritics at $0.003 \mathrm{mmHg}$ and $-196^{\circ} \mathrm{C}$. Before analysis, 
the samples were degassed under $0.350 \mathrm{mmHg}$ for $30 \mathrm{~min}$ at $25^{\circ} \mathrm{C}$ followed by fast-mode degassing at $280{ }^{\circ} \mathrm{C}$ overnight.

The powder X-ray diffraction (XRD) analyses were performed using a Rigaku diffractometer with $\mathrm{Cu} \mathrm{K} \alpha$ radiation $(\lambda=0.1540 \mathrm{~nm})$ as the source.

Small-angle X-ray scattering (SAXS) patterns of the materials were recorded using a D8 Advance X-ray diffractometer (Bruker) equipped with a Nanostar Hi Star 2D area detector using $\mathrm{Cu}-\mathrm{K} \alpha 1$ radiation $(\lambda=0.15406 \mathrm{~nm})$ with a voltage of $40 \mathrm{kV}$ and a current of $40 \mathrm{~mA}$.

Transmission electron microscopy (TEM) studies were undertaken using a JEM-2100F operating at an accelerating voltage of $200 \mathrm{kV}$. TEM instrument equipped with a Gatan Orius SC1000 CCD camera.

A K-5 Alpha XPS instrument (Thermo) at a pressure less than $10^{-8}$ Torr was used to study the X-ray photoelectron spectroscopy (XPS) of the surface of the catalysts. The survey scan and Si 3d, $\mathrm{Ni} 2 \mathrm{p}$, and $\mathrm{O} 1 \mathrm{~s}$ core level spectra were recorded using $\mathrm{Al} \mathrm{K} \alpha$ radiation. All binding energies were calibrated with reference to the $\mathrm{C} 1$ s peak at $284.6 \mathrm{eV}$ arising from the hydrocarbons adsorbed from the atmosphere.

Fourier transform infrared spectroscopy (FTIR) was performed using a Frontier FT-IR/FIR spectrometer (Perkin Elmer) in the range between 400 and $4000 \mathrm{~cm}^{-1}$.

\subsection{Catalytic Activity Test}

The catalysts were pre-reduced in situ in a mixed flow of hydrogen and helium $\left(10: 40 \mathrm{~mL} \mathrm{~min}^{-1}\right)$ at $700{ }^{\circ} \mathrm{C}$ for $2 \mathrm{~h}$, which is henceforth referred to as reduced catalysts. The performance of all catalysts was tested at the same conditions over the reduced catalysts under a gas hourly space velocity (GHSV) of $52,000 \mathrm{~mL} \mathrm{~g}^{-1} \mathrm{~h}^{-1}$ at $700{ }^{\circ} \mathrm{C}$ and atmospheric pressure in a fixed-bed continuous flow quartz reactor. The catalyst mass was $100 \mathrm{mg}$. The catalyst particle size was kept within the range of $500-710 \mu \mathrm{m}$. It had been found that under these conditions there were no any internal or external mass transfer limitations (based on the calculation of the Weisz criterion [96]) $[19,24,97]$. The product gas mixture was analysed by on-line gas chromatography (gas chromatography-PerkinElmer Clarus 580 GC) equipped with a silica packed column and a thermal conductivity detector.

\section{Conclusions}

From this study, it could be seen that Ni supported on TMS showed the highest activity among all the catalysts that were tested as well as the Ni catalysts supported on classic ordered mesoporous silicates support reported in the literature under similar conditions. While Ni supported on MCM-41 exhibited the least activity among all examined catalysts. The results presented in the present study showed that the morphology of mesoporous supports, in particular, the thickness and the pore size of the silica wall play a substantial role in determining the catalytic performance of impregnated $\mathrm{Ni}$ catalysts on the mesoporous silica supports towards the $\mathrm{CO}_{2}$ reforming of methane. It has been shown that the small pore diameters and thin silica walls in the support material were less favoured for the catalytic activity of impregnated nickel catalysts, due to their inability to prevent nickel sintering and through reducing the accessibility of the reactants to $\mathrm{Ni}$ particles embedded inside the pores and removal of products. These findings will help researchers to develop more active supported $\mathrm{Ni}$ catalysts which can find wide application in heterogeneous catalysis such as the catalytic $\mathrm{CO}_{2}$ reforming of methane.

Funding: This research received no external funding.

Acknowledgments: The author thanks Suresh K. Bhargava and the Centre for Advanced Materials and Industrial Chemistry, School of Science, RMIT University for financial support. Also, the author thanks Blake Plowman, Samuel Ippolito, Frank Antolasic, Selvakannan Periasamy, Moein Amin and Azin Amin for their help acquiring the data and helpful discussions. The author acknowledges the facilities, and the scientific and technical assistance, of the Australian Microscopy \& Microanalysis Research Facility at the RMIT Microscopy \& Microanalysis Facility, at RMIT University.

Conflicts of Interest: There are no conflict to declare. 


\section{References}

1. Kresge, C.T.; Leonowicz, M.E.; Roth, W.J.; Vartuli, J.C.; Beck, J.S. Ordered mesoporous molecular sieves synthesized by a liquid-crystal template mechanism. Nature 1992, 359, 710. [CrossRef]

2. Zhao, X.S.; Lu, G.Q.; Millar, G.J. Advances in Mesoporous Molecular Sieve MCM-41. Ind. Eng. Chem. Res. 1996, 35, 2075-2090. [CrossRef]

3. Akolekar, D.B.; Bhargava, S.K. Investigations on gold nanoparticles in mesoporous and microporous materials. J. Mol. Catal. A Chem. 2005, 236, 77-86. [CrossRef]

4. Vallet-Regi, M.; Rámila, A.; del Real, R.P.; Pérez-Pariente, J. A New Property of MCM-41: Drug Delivery System. Chem. Mater. 2001, 13, 308-311. [CrossRef]

5. Wei, J.; Qian, Y.; Wang, L.; Ge, Y.; Su, L.; Zhai, D.; Wang, J.; Wang, J.; Yu, J. Enhancement of Degradation and Dechlorination of Trichloroethylene via Supporting Palladium/Iron Bimetallic Nanoparticles onto Mesoporous Silica. Catalysts 2016, 6, 105. [CrossRef]

6. Yu, J.; Shen, A.; Cao, Y.; Lu, G. Preparation of Pd-Diimine@SBA-15 and Its Catalytic Performance for the Suzuki Coupling Reaction. Catalysts 2016, 6, 181. [CrossRef]

7. Carrero, A.; Calles, J.A.; García-Moreno, L.; Vizcaíno, A.J. Production of Renewable Hydrogen from Glycerol Steam Reforming over Bimetallic Ni-(Cu,Co,Cr) Catalysts Supported on SBA-15 Silica. Catalysts 2017, 7, 55. [CrossRef]

8. Moreno, J.; Iglesias, J.; Melero, J.A. Mo(VI) Complexes Immobilized on SBA-15 as an Efficient Catalyst for 1-Octene Epoxidation. Catalysts 2017, 7, 215. [CrossRef]

9. Al-Fatesh, A.S.; Ibrahim, A.A.; Abu-Dahrieh, J.K.; Al-Awadi, A.S.; El-Toni, A.M.; Fakeeha, A.H.; Abasaeed, A.E. Gallium-Promoted Ni Catalyst Supported on MCM-41 for Dry Reforming of Methane. Catalysts 2018, 8, 229. [CrossRef]

10. Li, R.; Song, H.; Chen, J. Propylsulfonic Acid Functionalized SBA-15 Mesoporous Silica as Efficient Catalysts for the Acetalization of Glycerol. Catalysts 2018, 8, 297. [CrossRef]

11. Martínez-Edo, G.; Balmori, A.; Pontón, I.; Martí del Rio, A.; Sánchez-García, D. Functionalized Ordered Mesoporous Silicas (MCM-41): Synthesis and Applications in Catalysis. Catalysts 2018, 8, 617. [CrossRef]

12. Meshksar, M.; Rahimpour, M.R.; Daneshmand-Jahromi, S.; Hafizi, A. Synthesis and Application of Cerium-Incorporated SBA-16 Supported Ni-Based Oxygen Carrier in Cyclic Chemical Looping Steam Methane Reforming. Catalysts 2018, 8, 18. [CrossRef]

13. Jiraroj, D.; Tongtooltush, T.; Panpranot, J.; Praserthdam, P.; Tungasmita, D.N. Catalytic Cracking of Biodiesel Waste Using Metal Supported SBA-15 Mesoporous Catalysts. Catalysts 2019, 9, 291. [CrossRef]

14. Wróblewska, A.; Miądlicki, P.; Tołpa, J.; Sreńscek-Nazzal, J.; Koren, Z.C.; Michalkiewicz, B. Influence of the Titanium Content in the Ti-MCM-41 Catalyst on the Course of the $\alpha$-Pinene Isomerization Process. Catalysts 2019, 9, 396. [CrossRef]

15. Zhao, D.; Feng, J.; Huo, Q.; Melosh, N.; Fredrickson, G.H.; Chmelka, B.F.; Stucky, G.D. Triblock Copolymer Syntheses of Mesoporous Silica with Periodic 50 to 300 Angstrom Pores. Science 1998, 279, 548-552. [CrossRef]

16. Kleitz, F.; Hei Choi, S.; Ryoo, R. Cubic Ia3d large mesoporous silica: Synthesis and replication to platinum nanowires, carbon nanorods and carbon nanotubes. Chem. Commun. 2003, 17, 2136-2137. [CrossRef]

17. Amin, M.H. A Mini-Review on $\mathrm{CO}_{2}$ Reforming of Methane. Prog. Petrochem. Sci 2018, 2, PPS.000532.2018.

18. Amin, M.H.; Mantri, K.; Newnham, J.; Tardio, J.; Bhargava, S.K. Highly stable ytterbium promoted Ni/ $\gamma-\mathrm{Al}_{2} \mathrm{O}_{3}$ catalysts for carbon dioxide reforming of methane. Appl. Catal. B Environ. 2012, 119, 217-226. [CrossRef]

19. Newnham, J.; Mantri, K.; Amin, M.H.; Tardio, J.; Bhargava, S.K. Highly stable and active Ni-mesoporous alumina catalysts for dry reforming of methane. Int. J. Hydrog. Energy 2012, 37, 1454-1464. [CrossRef]

20. Amin, M.H.; Tardio, J.; Bhargava, S.K. An investigation on the role of ytterbium in ytterbium promoted $\gamma$-alumina-supported nickel catalysts for dry reforming of methane. Int. J. Hydrog. Energy 2013, 38, 14223-14231. [CrossRef]

21. Amin, M.H.T.; Bhargava, J.; Suresh, K. An investigation on the role of promoters in promoted $\gamma$-alumina-supported nickel catalysts for dry reforming of methane. In Chemeca 2013: Challenging Tomorrow; Barton ACT; Engineers Australia Brisbane: Brisbane, Australia, 2013; pp. 549-557. 
22. Amin, M.H.; Bhargava, J.T.S.K. A Comparison Study on Methane Dry Reforming with Carbon Dioxide over Ni Catalysts Supported on Mesoporous SBA-15, MCM-41, KIT-6 and $\gamma$-Al2O3 Carrier; Chemeca 2013, Brisbane Convention \& Exhibition Centre, Australia, Chemeca 2013: Challenging Tomorrow; Barton, ACT; Brisbane Convention \& Exhibition Centre; Engineers Australia: Brisbane, Australia, 2013; pp. 543-548.

23. Amin, M.H.; Putla, S.; Hamid, S.B.A.; Bhargava, S.K. Understanding the role of lanthanide promoters on the structure-activity of nanosized $\mathrm{Ni} / \gamma-\mathrm{Al}_{2} \mathrm{O}_{3}$ catalysts in carbon dioxide reforming of methane. Appl. Catal. A Gen. 2015, 492, 160-168. [CrossRef]

24. Amin, M.H.; Sudarsanam, P.; Field, M.R.; Patel, J.; Bhargava, S.K. Effect of a Swelling Agent on the Performance of Ni/Porous Silica Catalyst for $\mathrm{CH}_{4}-\mathrm{CO}_{2}$ Reforming. Langmuir 2017, 33, 10632-10644. [CrossRef] [PubMed]

25. De Vasconcelos, B.R.; Minh, D.P.; Sharrock, P.; Nzihou, A. Regeneration study of Ni/hydroxyapatite spent catalyst from dry reforming. Catal. Today 2018, 310, 107-115. [CrossRef]

26. Şener, A.N.; Günay, M.E.; Leba, A.; Yıldırım, R. Statistical review of dry reforming of methane literature using decision tree and artificial neural network analysis. Catal. Today 2018, 299, 289-302. [CrossRef]

27. Shah, M.; Das, S.; Nayak, A.K.; Mondal, P.; Bordoloi, A. Smart designing of metal-support interface for imperishable dry reforming catalyst. Appl. Catal. A Gen. 2018, 556, 137-154. [CrossRef]

28. Li, B.; Su, W.; Wang, X.; Wang, X. Alumina supported Ni and Co catalysts modified by $\mathrm{Y}_{2} \mathrm{O}_{3}$ via different impregnation strategies: Comparative analysis on structural properties and catalytic performance in methane reforming with $\mathrm{CO}_{2}$. Int. J. Hydrog. Energy 2016, 41, 14732-14746. [CrossRef]

29. Yang, W.; He, D. Role of poly(N-vinyl-2-pyrrolidone) in Ni dispersion for highly-dispersed Ni/SBA-15 catalyst and its catalytic performance in carbon dioxide reforming of methane. Appl. Catal. A Gen. 2016, 524, 94-104. [CrossRef]

30. Kalai, D.Y.; Stangeland, K.; Jin, Y.; Yu, Z. Active and stable hydrotalcite derived Ni catalysts for $\mathrm{CO}_{2}$ reforming of methane: Comparison with catalysts by incipient wetness. J. Co2 Util. 2018, 25, 346-355. [CrossRef]

31. Sokolov, S.; Kondratenko, E.V.; Pohl, M.-M.; Barkschat, A.; Rodemerck, U. Stable low-temperature dry reforming of methane over mesoporous $\mathrm{La}_{2} \mathrm{O}_{3}-\mathrm{ZrO}_{2}$ supported Ni catalyst. Appl. Catal. B Environ. 2012, 113, 19-30. [CrossRef]

32. Deactivation and Poisoning of Catalysts; Marcel Dekker, Inc.: New York, NY, USA; Basel, Switzerland, 1985; Volume 20, p. 270.

33. Xin, J.; Cui, H.; Cheng, Z.; Zhou, Z. Bimetallic Ni-Co/SBA-15 catalysts prepared by urea co-precipitation for dry reforming of methane. Appl. Catal. A Gen. 2018, 554, 95-104. [CrossRef]

34. Zhang, Q.; Zhang, T.; Shi, Y.; Zhao, B.; Wang, M.; Liu, Q.; Wang, J.; Long, K.; Duan, Y.; Ning, P. A sintering and carbon-resistant Ni-SBA-15 catalyst prepared by solid-state grinding method for dry reforming of methane. J. Co2 Util. 2017, 17, 10-19. [CrossRef]

35. Huang, X.; Xue, G.; Wang, C.; Zhao, N.; Sun, N.; Wei, W.; Sun, Y. Highly stable mesoporous $\mathrm{NiO}_{-} \mathrm{Y}_{2} \mathrm{O}_{3}-\mathrm{Al}_{2} \mathrm{O}_{3}$ catalysts for $\mathrm{CO}_{2}$ reforming of methane: Effect of Ni embedding and $\mathrm{Y}_{2} \mathrm{O}_{3}$ promotion. Catal. Sci. Technol. 2016, 6, 449-459. [CrossRef]

36. Singh, S.; Kumar, R.; Setiabudi, H.D.; Nanda, S.; Vo, D.-V.N. Advanced synthesis strategies of mesoporous SBA-15 supported catalysts for catalytic reforming applications: A state-of-the-art review. Appl. Catal. A Gen. 2018, 559, 57-74. [CrossRef]

37. Zheng, Y.; Geng, H.; Zhang, Y.; Chen, L.; Li, C.C. Precursor-Based Synthesis of Porous Colloidal Particles towards Highly Efficient Catalysts. Chem. A Eur. J. 2018, 24, 10280-10290. [CrossRef]

38. Yuan, E.; Wu, C.; Liu, G.; Li, G.; Wang, L. Effects of SBA-15 physicochemical properties on performance of Pd/SBA-15 catalysts in 2-ethyl-anthraquinone hydrogenation. J. Ind. Eng. Chem. 2018, 66, 158-167. [CrossRef]

39. Gao, Y.; Jiang, J.; Meng, Y.; Yan, F.; Aihemaiti, A. A review of recent developments in hydrogen production via biogas dry reforming. Energy Convers. Manag. 2018, 171, 133-155. [CrossRef]

40. Pham, X.N.; Nguyen, B.M.; Thi, H.T.; Van Doan, H. Synthesis of Ag-AgBr/Al-MCM-41 nanocomposite and its application in photocatalytic oxidative desulfurization of dibenzothiophene. Adv. Powder Technol. 2018, 29, 1827-1837. [CrossRef]

41. Shi, L.; Kai, W.; Yang, C.-F.; Qian, H.; Liu, D.-B.; Pan, R.-M. Synthesis, characterization of Nafion-functionalized MCM-41 and its catalytic application in preparation of CL-20 via HNO3 electrolyte involved nitration of TAIW. J. Saudi Chem. Soc. 2018, 22, 588-593. [CrossRef] 
42. Sohrabnezhad, S.; Jafarzadeh, A.; Pourahmad, A. Synthesis and characterization of MCM-41 ropes. Mater. Lett. 2018, 212, 16-19. [CrossRef]

43. Uhlig, H.; Muenster, T.; Kloess, G.; Ebbinghaus, S.G.; Einicke, W.-D.; Gläser, R.; Enke, D. Synthesis of MCM-48 granules with bimodal pore systems via pseudomorphic transformation of porous glass. Microporous Mesoporous Mater. 2018, 257, 185-192. [CrossRef]

44. Al-Fatesh, H.A.S.; Ibrahim, A.A.; Fakeeha, A.H.; Singh, S.K.; Labhsetwar, N.K.; Shaikh, H.; Qasim, S.O. CO 2 reforming of $\mathrm{CH}_{4}$ : Effect of $\mathrm{Gd}$ as promoter for Ni supported over MCM-41 as catalyst. Renew. Energy 2019, 140, 658-667. [CrossRef]

45. Al-Awadi, A.S.; El-Toni, A.M.; Alhoshan, M.; Khan, A.; Labis, J.P.; Al-Fatesh, A.; Abasaeed, A.E.; Al-Zahrani, S.M. Impact of precursor sequence of addition for one-pot synthesis of Cr-MCM-41 catalyst nanoparticles to enhance ethane oxidative dehydrogenation with carbon dioxide. Ceram. Int. 2019, 45, 1125-1134. [CrossRef]

46. Bernal, Y.P.; Alvarado, J.; Juárez, R.L.; Méndez Rojas, M.Á.; de Vasconcelos, E.A.; de Azevedo, W.M.; Iniesta, S.A.; Cab, J.V. Synthesis and characterization of MCM-41 powder and its deposition by spin-coating. Optik 2019, 185, 429-440. [CrossRef]

47. Li, X.; Lu, T.; Wang, Y.; Yang, Y. Study on the controllable synthesis of SH-MCM-41 mesoporous materials and their adsorption properties of the La3+, Gd3+ and Yb3+. Chin. Chem. Lett. 2019, 30, 2318-2322. [CrossRef]

48. Pei, Y.; Jiang, Z.; Yuan, L. Facile synthesis of MCM-41/MgO for highly efficient adsorption of organic dye. Colloids Surf. A Physicochem. Eng. Asp. 2019, 581, 123816. [CrossRef]

49. Rizzi, V.; Prasetyanto, E.A.; Chen, P.; Gubitosa, J.; Fini, P.; Agostiano, A.; De Cola, L.; Cosma, P. Amino grafted MCM-41 as highly efficient and reversible ecofriendly adsorbent material for the Direct Blue removal from wastewater. J. Mol. Liq. 2019, 273, 435-446. [CrossRef]

50. Santos, L.F.S.; de Jesus, R.A.; Costa, J.A.S.; Gouveia, L.G.T.; de Mesquita, M.E.; Navickiene, S. Evaluation of MCM-41 and MCM-48 mesoporous materials as sorbents in matrix solid phase dispersion method for the determination of pesticides in soursop fruit (Annona muricata). Inorg. Chem. Commun. 2019, 101, 45-51. [CrossRef]

51. Singh, S.; Nguyen, T.D.; Siang, T.J.; Phuong, P.T.T.; Phuc, N.H.; Truong, Q.D.; Lam, S.S.; Vo, D.-V.N. Boron-doped Ni/SBA-15 catalysts with enhanced coke resistance and catalytic performance for dry reforming of methane. J. Energy Inst. 2019, 93, 31-42. [CrossRef]

52. Sohrabnezhad, S.; Mooshangaie, S.D. In situ fabrication of n-type Ag/AgBr nanoparticles in MCM-41 with rice husk (RH/MCM-41) composite for the removal of Eriochrome Black-T. Mater. Sci. Eng. B 2019, 240, 16-22. [CrossRef]

53. Wu, H.; Liu, J.; Liu, H.; He, D. $\mathrm{CO}_{2}$ reforming of methane to syngas at high pressure over bi-component Ni-Co catalyst: The anti-carbon deposition and stability of catalyst. Fuel 2019, 235, 868-877. [CrossRef]

54. Sarkar, B.; Goyal, R.; Pendem, C.; Sasaki, T.; Bal, R. Highly nanodispersed Gd-doped Ni/ZSM-5 catalyst for enhanced carbon-resistant dry reforming of methane. J. Mol. Catal. A Chem. 2016, 424, 17-26. [CrossRef]

55. Schneider, D.; Mehlhorn, D.; Zeigermann, P.; Karger, J.; Valiullin, R. Transport properties of hierarchical micro-mesoporous materials. Chem. Soc. Rev. 2016, 45, 3439-3467. [CrossRef] [PubMed]

56. Guo, X.; Wang, R.; Yu, H.; Zhu, Y.; Nakanishi, K.; Kanamori, K.; Yang, H. Spontaneous preparation of hierarchically porous silica monoliths with uniform spherical mesopores confined in a well-defined macroporous framework. Dalton Trans. 2015, 44, 13592-13601. [CrossRef] [PubMed]

57. Taherian, Z.; Yousefpour, M.; Tajally, M.; Khoshandam, B. Catalytic performance of Samaria-promoted Ni and Co/SBA-15 catalysts for dry reforming of methane. Int. J. Hydrog. Energy 2017, 42, 24811-24822. [CrossRef]

58. Omoregbe, O.; Danh, H.T.; Nguyen-Huy, C.; Setiabudi, H.D.; Abidin, S.Z.; Truong, Q.D.; Vo, D.-V.N. Syngas production from methane dry reforming over Ni/SBA-15 catalyst: Effect of operating parameters. Int. J. Hydrog. Energy 2017, 42, 11283-11294. [CrossRef]

59. Taherian, Z.; Yousefpour, M.; Tajally, M.; Khoshandam, B. A comparative study of $\mathrm{ZrO}_{2}, \mathrm{Y}_{2} \mathrm{O}_{3}$ and $\mathrm{Sm}_{2} \mathrm{O}_{3}$ promoted Ni/SBA-15 catalysts for evaluation of $\mathrm{CO}_{2} /$ methane reforming performance. Int. J. Hydrog. Energy 2017, 42, 16408-16420. [CrossRef]

60. Zhang, Q.; Long, K.; Wang, J.; Zhang, T.; Song, Z.; Lin, Q. A novel promoting effect of chelating ligand on the dispersion of Ni species over Ni/SBA-15 catalyst for dry reforming of methane. Int. J. Hydrog. Energy 2017, 42, 14103-14114. [CrossRef] 
61. Erdogan, B.; Arbag, H.; Yasyerli, N. SBA-15 supported mesoporous Ni and Co catalysts with high coke resistance for dry reforming of methane. Int. J. Hydrog. Energy 2018, 43, 1396-1405. [CrossRef]

62. Świrk, K.; Gálvez, M.E.; Motak, M.; Grzybek, T.; Rønning, M.; Da Costa, P. Syngas production from dry methane reforming over yttrium-promoted nickel-KIT-6 catalysts. Int. J. Hydrog. Energy 2018, 44, 274-286. [CrossRef]

63. Frontera, P.; Macario, A.; Aloise, A.; Antonucci, P.L.; Giordano, G.; Nagy, J.B. Effect of support surface on methane dry-reforming catalyst preparation. Catal. Today 2013, 218, 18-29. [CrossRef]

64. Usman, M.; Wan Daud, W.M.A.; Abbas, H.F. Dry reforming of methane: Influence of process parameters-A review. Renew. Sustain. Energy Rev. 2015, 45, 710-744. [CrossRef]

65. Arora, S.; Prasad, R. An overview on dry reforming of methane: Strategies to reduce carbonaceous deactivation of catalysts. RSC Adv. 2016, 6, 108668-108688. [CrossRef]

66. Zhang, G.; Liu, J.; Xu, Y.; Sun, Y. A review of $\mathrm{CH}_{4}-\mathrm{CO}_{2}$ reforming to synthesis gas over Ni-based catalysts in recent years (2010-2017). Int. J. Hydrog. Energy 2018, 43, 15030-15054. [CrossRef]

67. Sing, K.S.W.; Haul, D.H.E.R.A.W.; Moscou, L.; Pierotti, R.A.; Rouquérol, J. Siemieniewska Reporting Physisorption Data for Gas/Solid Systems With Special Reference to the Determination of Surface Area and Porosity. Pure Appl. Chem. 1985, 57, 603. [CrossRef]

68. Zhao, D.; Huo, Q.; Feng, J.; Chmelka, B.F.; Stucky, G.D. Nonionic Triblock and Star Diblock Copolymer and Oligomeric Surfactant Syntheses of Highly Ordered, Hydrothermally Stable, Mesoporous Silica Structures. J. Am. Chem. Soc. 1998, 120, 6024-6036. [CrossRef]

69. Huang, T.; Huang, W.; Huang, J.; Ji, P. Methane reforming reaction with carbon dioxide over SBA-15 supported Ni-Mo bimetallic catalysts. Fuel Process. Technol. 2011, 92, 1868-1875. [CrossRef]

70. Damyanova, S.; Pawelec, B.; Arishtirova, K.; Fierro, J.L.G.; Sener, C.; Dogu, T. MCM-41 supported PdNi catalysts for dry reforming of methane. Appl. Catal. B Environ. 2009, 92, 250-261. [CrossRef]

71. Méndez, F.J.; Llanos, A.; Echeverría, M.; Jáuregui, R.; Villasana, Y.; Díaz, Y.; Liendo-Polanco, G.; Ramos-García, M.A.; Zoltan, T.; Brito, J.L. Mesoporous catalysts based on Keggin-type heteropolyacids supported on MCM-41 and their application in thiophene hydrodesulfurization. Fuel 2013, 110, 249-258. [CrossRef]

72. Beck, J.S.; Vartuli, J.C.; Roth, W.J.; Leonowicz, M.E.; Kresge, C.T.; Schmitt, K.D.; Chu, C.T.W.; Olson, D.H.; Sheppard, E.W.; McCullen, S.B.; et al. A new family of mesoporous molecular sieves prepared with liquid crystal templates. J. Am. Chem. Soc. 1992, 114, 10834-10843. [CrossRef]

73. Qin, F.; Anderegg, J.W.; Jenks, C.J.; Gleeson, B.; Sordelet, D.J.; Thiel, P.A. X-ray photoelectron spectroscopy studies of the early-stage oxidation behavior of (Pt, Ni)3Al(111) surfaces in air. Surf. Sci. 2008, 602, 205-215. [CrossRef]

74. Rumble, J.R., Jr.; Bickham, D.M.; Powell, C.J. NIST X-ray Photoelectron Spectroscopy Database. Surf. Interface Anal. 1992, 19, 241-246. [CrossRef]

75. Sudhakar, M.; Kumar, V.V.; Naresh, G.; Kantam, M.L.; Bhargava, S.K.; Venugopal, A. Vapor phase hydrogenation of aqueous levulinic acid over hydroxyapatite supported metal $(\mathrm{M}=\mathrm{Pd}, \mathrm{Pt}, \mathrm{Ru}, \mathrm{Cu}, \mathrm{Ni})$ catalysts. Appl. Catal. B Environ. 2016, 180, 113-120. [CrossRef]

76. Chukin, G.D.; Malevich, V.I. Infrared spectra of silica. J. Appl. Spectrosc. 1977, 26, 223-229. [CrossRef]

77. Li, J.F.; Xia, C.; Au, C.T.; Liu, B.S. $\mathrm{Y}_{2} \mathrm{O}_{3}$-promoted NiO/SBA- 15 catalysts highly active for $\mathrm{CO}_{2} / \mathrm{CH}_{4}$ reforming. Int. J. Hydrog. Energy 2014, 39, 10927-10940. [CrossRef]

78. Schmidt-Winkel, P.; Lukens, W.W.; Zhao, D.; Yang, P.; Chmelka, B.F.; Stucky, G.D. Mesocellular Siliceous Foams with Uniformly Sized Cells and Windows. J. Am. Chem. Soc. 1999, 121, 254-255. [CrossRef]

79. Xu, L.; Song, H.; Chou, L. Mesoporous nanocrystalline ceria-zirconia solid solutions supported nickel based catalysts for $\mathrm{CO}_{2}$ reforming of $\mathrm{CH}_{4}$. Int. J. Hydrog. Energy 2012, 37, 18001-18020. [CrossRef]

80. Xie, T.; Shi, L.; Zhang, J.; Zhang, D. Immobilizing Ni nanoparticles to mesoporous silica with size and location control via a polyol-assisted route for coking- and sintering-resistant dry reforming of methane. Chem. Commun. 2014, 50, 7250-7253. [CrossRef]

81. Wang, N.; Yu, X.; Shen, K.; Chu, W.; Qian, W. Synthesis, characterization and catalytic performance of MgO-coated Ni/SBA-15 catalysts for methane dry reforming to syngas and hydrogen. Int. J. Hydrog. Energy 2013, 38, 9718-9731. [CrossRef] 
82. Gálvez, M.E.; Albarazi, A.; Da Costa, P. Enhanced catalytic stability through non-conventional synthesis of Ni/SBA-15 for methane dry reforming at low temperatures. Appl. Catal. A Gen. 2015, 504, 143-150. [CrossRef]

83. Jafarbegloo, M.; Tarlani, A.; Mesbah, A.W.; Sahebdelfar, S. One-pot synthesis of NiO-MgO nanocatalysts for $\mathrm{CO}_{2}$ reforming of methane: The influence of active metal content on catalytic performance. J. Nat. Gas Sci. Eng. 2015, 27, 1165-1173. [CrossRef]

84. El Hassan, N.; Kaydouh, M.N.; Geagea, H.; El Zein, H.; Jabbour, K.; Casale, S.; El Zakhem, H.; Massiani, P. Low temperature dry reforming of methane on rhodium and cobalt based catalysts: Active phase stabilization by confinement in mesoporous SBA-15. Appl. Catal. A Gen. 2016, 520, 114-121. [CrossRef]

85. Rodriguez-Gomez, A.; Pereñiguez, R.; Caballero, A. Nickel Particles Selectively Confined in the Mesoporous Channels of SBA-15 Yielding a Very Stable Catalyst for DRM Reaction. J. Phys. Chem. B 2018, 122, 500-510. [CrossRef] [PubMed]

86. Ungureanu, A.; Dragoi, B.; Chirieac, A.; Ciotonea, C.; Royer, S.; Duprez, D.; Mamede, A.S.; Dumitriu, E. Composition-Dependent Morphostructural Properties of Ni-Cu Oxide Nanoparticles Confined within the Channels of Ordered Mesoporous SBA-15 Silica. ACS Appl. Mater. Interfaces 2013, 5, 3010-3025. [CrossRef] [PubMed]

87. Rodriguez-Gomez, A.; Caballero, A. Identification of Outer and Inner Nickel Particles in a Mesoporous Support: How the Channels Modify the Reducibility of Ni/SBA-15 Catalysts. ChemNanoMat 2017, 3, 94-97. [CrossRef]

88. Qiu, S.; Zhang, Q.; Lv, W.; Wang, T.; Zhang, Q.; Ma, L. Simply packaging Ni nanoparticles inside SBA-15 channels by co-impregnation for dry reforming of methane. RSC Adv. 2017, 7, 24551-24560. [CrossRef]

89. Guidelines for Mastering the Properties of Molecular Sieves: Relationship between the Physicochemical Properties of Zeolitic Systems and Their Low Dimensionality; Springer Science \& Business Media: New York, NY, USA; London, UK, 1989; Volume 221, p. 438.

90. Liu, D.; Quek, X.-Y.; Wah, H.H.A.; Zeng, G.; Li, Y.; Yang, Y. Carbon dioxide reforming of methane over nickel-grafted SBA-15 and MCM-41 catalysts. Catal. Today 2009, 148, 243-250. [CrossRef]

91. Wang, N.; Yu, X.; Wang, Y.; Chu, W.; Liu, M. A comparison study on methane dry reforming with carbon dioxide over $\mathrm{LaNiO}_{3}$ perovskite catalysts supported on mesoporous SBA-15, MCM-41 and silica carrier. Catal. Today 2013, 212, 98-107. [CrossRef]

92. Albarazi, A.; Beaunier, P.; Da Costa, P. Hydrogen and syngas production by methane dry reforming on SBA-15 supported nickel catalysts: On the effect of promotion by $\mathrm{Ce}_{0.75} \mathrm{Zr}_{0.25} \mathrm{O}_{2}$ mixed oxide. Int. J. Hydrog. Energy 2013, 38, 127-139. [CrossRef]

93. Kawi, S.; Kathiraser, Y.; Ni, J.; Oemar, U.; Li, Z.; Saw, E.T. Progress in Synthesis of Highly Active and Stable Nickel-Based Catalysts for Carbon Dioxide Reforming of Methane. ChemSusChem 2015, 8, 3556-3575. [CrossRef]

94. Xu, L.; Song, H.; Chou, L. Carbon dioxide reforming of methane over ordered mesoporous $\mathrm{NiO}-\mathrm{MgO}_{\mathrm{O}}-\mathrm{Al}_{2} \mathrm{O}_{3}$ composite oxides. Appl. Catal. B Environ. 2011, 108, 177-190. [CrossRef]

95. Corma, A. From Microporous to Mesoporous Molecular Sieve Materials and Their Use in Catalysis. Chem. Rev. 1997, 97, 2373-2420. [CrossRef] [PubMed]

96. Bradford, M.C.J.; Vannice, M.A. Catalytic reforming of methane with carbon dioxide over nickel catalysts I. Catalyst characterization and activity. Appl. Catal. A Gen. 1996, 142, 73-96. [CrossRef]

97. Amin, M.H.T.; Bhargava, J.; Suresh, K. A comparison study on carbon dioxide reforming of methane over Ni catalysts supported on mesoporous SBA-15, MCM-41, KIT-6 and gamma- $\mathrm{Al}_{2} \mathrm{O}_{3}$. In Chemeca 2013: Challenging Tomorrow; Barton, ACT; Engineers Australia: Brisbane, Australia, 2013; pp. 543-548.

(C) 2020 by the author. Licensee MDPI, Basel, Switzerland. This article is an open access article distributed under the terms and conditions of the Creative Commons Attribution (CC BY) license (http://creativecommons.org/licenses/by/4.0/). 